Institut de recherche pour le développement

\title{
Informal Sector Dynamics In Times Of Fragile Growth: The Case Of Madagascar
}

\section{Michael GRIMM}

Jann LAY

François ROUBAUD

Julia VAILLANT

Place du Maréchal de Lattre de Tassigny 75775• Paris Cedex 16 •Tél. (33) 0144054542 • Fax (33) 0144054545 • 4, rue d’Enghien • 75010 Paris • Tél. (33) 01532414 50 • Fax (33) 0153241451

E-mail : dial@dial.prd.fr • Site : www.dial.prd.fr 


\title{
INFORMAL SECTOR DYNAMICS IN TIMES OF FRAGILE GROWTH: THE CASE OF MADAGASCAR ${ }^{1}$
}

\author{
Michael Grimm \\ ISS \\ Erasmus University Rotterdam, The Hague \\ grimm@iss.nl \\ François Roubaud \\ IRD, UMR 225-DIAL \\ Université Paris-Dauphine \\ roubaud@dial.prd.fr
}

\author{
Jann Lay \\ German Institute of Global and Area Studies, \\ Hamburg \\ lay@giga-hamburg.de \\ Julia Vaillant \\ IRD, UMR 225-DIAL \\ Université Paris-Dauphine \\ vaillant@dial.prd.fr
}

Document de travail UMR DIAL

Septembre 2011

\begin{abstract}
This paper investigates the dynamics of the informal sector in Madagascar during a period of fragile growth. Overall, the behavior of informal firms in terms of earnings, employment and capital accumulation points to a degree of heterogeneity which goes beyond a simple dualistic model and even a more refined model that would distinguish between an upper entrepreneurial and a lower subsistence tier within the informal sector. However, in line with the dualistic model, the informal sector indeed fulfils a labor absorbing function in times of crisis. During the growth period we see capital accumulation in most of the sectors and lots of evidence that households expand their activities. However, this happens mainly through the creation of new firms instead of the expansion of existing ones, which is consistent with much higher returns at very low levels of capital. More rapid expansion can be observed in sectors that operate with lower capital intensity, which is also consistent with risk or credit constraints as major deterrents to expansion. While there is some indication that total factor productivity increased over time, returns to capital and labor where not higher at the end of the observation period than at the beginning. Returns are also rather low at high levels of capital. These findings point to a limited growth potential of the informal sector as a whole. The heterogeneity in capital returns hints at large inefficiencies in allocating capital across informal firms.
\end{abstract}

Keywords: Informal sector, microenterprise, firm growth, capital returns, Madagascar.

\section{Résumé}

Cet article examine la dynamique du secteur informel à Madagascar pendant une période de croissance fragile. Le comportement des firmes informelles en termes de revenus, d'emploi et d'accumulation du capital suggère un degré d'hétérogénéité allant au-delà du modèle dualiste classique, et même d'un modèle plus fin distinguant, au sein du secteur informel, un segment entrepreneurial et un segment de subsistance. Cependant, conformément au modèle dualiste, le secteur informel a absorbé le surplus de travail en temps de crise. Pendant la période de croissance, on constate une accumulation de capital dans la plupart des secteurs d'activité et une expansion des activités des ménages. Ceci se traduit pourtant principalement par la création de nouvelles firmes plutôt que par la croissance de firmes existantes, en lien avec des rendements beaucoup plus élevés à des faibles niveaux de capital. Une expansion plus rapide peut être observée dans les secteurs à faible intensité capitalistique, ce qui tend également à confirmer que le risque et les contraintes de crédit sont des obstacles à l'expansion. Alors que les résultats montrent que la productivité totale des facteurs a augmenté, les rendements du capital et du travail ne sont pas plus élevés à la fin de la période étudiée qu'au début. Les rendements sont également plutôt faibles à des niveaux élevés de capital. Ces résultats indiquent un potentiel de croissance globalement limité des firmes informelles. Enfin, l’hétérogénéité des rendements du capital plaide en faveur d'une allocation sous-optimale du capital dans le secteur informel.

Mots clés : Secteur informel, micro-entreprises, croissance des firmes, rendement du capital, Madagascar.

JEL Classification: O12, O17, L26, D22.

This research is part of a project entitled "Unlocking potential: Tackling economic, institutional and social constraints of informal entrepreneurship in Sub-Saharan Africa” (http://www.iss.nl/informality) funded by the Austrian, German, Norwegian, Korean and Swiss Government through the World Bank’s Multi Donor Trust Fund Project: "Labor Markets, Job Creation, and Economic Growth, Scaling up Research, Capacity Building, and Action on the Ground”. The financial support is gratefully acknowledged. We thank participants at the CSAE 2011 Annual Conference in Oxford, at the Development Economics Conference 2011 of the German Economic Association in Berlin and at the DIAL Development Conference "Shocks in developing countries" in Paris for useful comments and suggestions. 


\section{Introduction}

The informal sector is the main source of income and employment for most urban households in the developing world. This sector was traditionally viewed as the low-productive, subsistence sector of urban areas, bound to disappear with economic growth. However, this process did not materialize and the sector grew in size in many of these countries. While the dualistic model of informal and formal sectors was challenged as early as the seventies (Hart, 1973; Moser, 1978), studies of informal activities which explicitly stressed their heterogeneous nature began to develop in the nineties (Fields, 2004; Bosch and Maloney, 2010). The informal sector comprises various forms of production and employment typically in micro and small enterprises (MSEs). While some of these informal firms may indeed represent a form of urban subsistence production, the informal sector is usually also the host of a significant number of successful entrepreneurs. Indeed recent research on MSEs in developing countries consistently finds rather high returns to capital in microenterprises (Fajnzylber, et al., 2006; McKenzie and Woodruff, 2006; De Mel, et al., 2008; Kremer, et al., 2008; Grimm, et al., 2011) suggesting that this sector has potential and is not just catering for subsistence production. Heterogeneity contradicts the assertion that sustained economic growth shrinks the informal sector until it disappears. Little is known about the way informal firms react to (or shape) overall macroeconomic dynamics, in particular over long periods. Yet, there is a small literature that examines the cyclical behavior of the informal sector (Maloney, 2004; Bosch and Maloney, 2010). Because of the heterogeneity of informal firms, there are no straightforward predictions on how size, structure and performance of the informal sector and the firms constituting it change during long periods of economic growth or spells of crisis. This paper is an attempt to provide some evidence on such changes for the Malagasy economy between 1995 and 2004.

Between 1995 and 2001, Madagascar experienced an exceptional period of economic expansion. The informal sector - defined as employment in unincorporated enterprises that are not registered or do not keep any written accounts ${ }^{2}$ - accounted then for 50-60\% of employment in Madagascar's capital Antananarivo and growth appeared to be associated to a decline in this share. In the first half of 2002, the major political crisis following the presidential elections of December 2001 reversed this trend, as general strikes, roadblocks and the vacancy of power caused a temporary collapse of GDP growth and a massive departure of foreign industries in particular those located in special Export Processing Zones (EPZ). The recent internal political and global financial crises have caused an even greater informalization of the economy, concentrating 65\% of total employment in Antananarivo in 2010.

These first figures suggest that the informal sector in Madagascar - a country without substantial unemployment insurance schemes or social safety nets - fulfills a labor absorbing function in times of economic downturns. Yet, this is only one of the facets of the informal sector. While the heterogeneity of informal activities is well-established in the literature, the dynamic implications of this heterogeneity are less acknowledged and understood. Based on the simplifying assumption of an upper (or entrepreneurial) tier and a lower (subsistence) tier of informal activities, the literature suggest procyclical behavior - that is moving with the aggregate production - in the upper tier and countercyclical behavior in the lower tier (Bosch and Maloney, 2010). Hence, both tiers are expected to differ in their response to cyclical movements. They are typically also expected to behave differently during periods of growth. Capital accumulation would only be expected in the upper tier, while subsistence activities would be expected to be caught in a poverty trap and stagnate at low levels of capital.

\footnotetext{
${ }^{2}$ This definition follows the ILO recommendation (1993).
} 
Similarly, total factor productivity would be expected to be low and stagnant in the lower tier, with productivity gains being limited to upper tier firms.

Based on the recent evidence mentioned above, we think that this distinction of an upper and lower tier is too simplistic and hides the high potential of many firms at the lower end of the capital distribution. Taking this as a background, this paper attempts to answer the following questions: which transformations occurred in the informal sector in the decade under review? In particular, which activities expanded and contracted in terms of employment and capital? Do returns to capital and labor increase or decrease with economic expansion? How do all these changes relate to the macroeconomic dynamics? To answer these questions, we rely on a quite unique dataset of four representative and perfectly comparable cross-sectional surveys of informal enterprises in Antananarivo in 1995, 1998, 2001 and 2004, i.e. before and after the 2002 crisis. This dataset allows a detailed description of the characteristics of the informal sector and its firms during a relatively long period of sustained growth, followed by a crisis and two years of recovery.

The remainder of the paper is organized as follows. In Section 2, we briefly present the economic and political context in Madagascar over the 1995 to 2005 period. In Section 3 we discuss the theoretical framework and the related empirical literature. In Section 4 we describe the data and main characteristics of the informal firms we analyze. In Section 5 we present our results organized in five sub-sections. We start by analyzing the patterns of firm growth and capital accumulation over time taking into account the heterogeneity of informal firms by systematically disaggregating by sector. Then, building on the recent empirical literature on returns to capital in small-scale activities in developing countries, we estimate profit functions to evaluate capital and labor returns in different segments of the capital distribution. By adding year interactions we study changes in these returns over time. In addition, specific sector returns are estimated. A more aggregate level of analysis is adopted in the last section that presents the results of the estimation of a sectoral profit function, using a pseudo-panel approach. Section 6 concludes.

\section{The economic and political context in Madagascar (1995-2005)}

After a long period of economic recession which started with the country's independence in 1960 and interrupted only by very short periods of growth, Madagascar experienced an exceptional period of economic expansion between 1997 and 2001. Several factors, both economic and political, drove this favorable development. Firstly, the political stability since the election of Didier Ratsiraka in 1996 and agreements with the Bretton Woods institutions to reduce debt created a favorable environment for investment. Secondly, the development of EPZs attracted foreign industry, in particular textile, which stimulated exports and employment. The rise of tourism also contributed to economic growth.

The presidential elections of December 2001 triggered a serious political crisis that lasted six months and had catastrophic economic effects (Razafindrakoto and Roubaud, 2002). The candidate Marc Ravalomanana challenged the first round results that he claimed were fraudulent. He maintained to have won the elections and refused the holding of a second round, against the incumbent president, Didier Ratsiraka. After huge demonstrations and general strikes, the conflict intensified as roadblocks around Antananarivo were set up by followers of Didier Ratsiraka in an attempt to paralyze the economy of the capital city. Finally, Marc Ravalomana was proclaimed president in May, and Didier Ratsiraka left the country in July 2002.

As shown in Figure 1, the political crisis had disastrous effects on the economy: GDP declined by $12.7 \%$ and inflation was close to $16 \%$ in 2002 (Gubert and Robilliard, 2010). Exports and foreign direct investments fell sharply, unemployment rose by $71 \%$ between mid-2001 and the end of 2002 
(Cling, et al., 2005). The share of employment in the informal sector grew again, as workers were laid off from the private sector, in particular in the EPZs, which were hit hard by the crisis. Despite the severity of the economic downturn, recovery was quick, with GDP growth of $9.8 \%$ in 2003 and around 5\% in the two following years. However, unemployment doubled between 2001 and 2005 and in the main urban areas increased from $4.4 \%$ to $12 \%$. Income per capita in 2004 also remained under its pre-crisis level (Gubert and Robilliard, 2010).

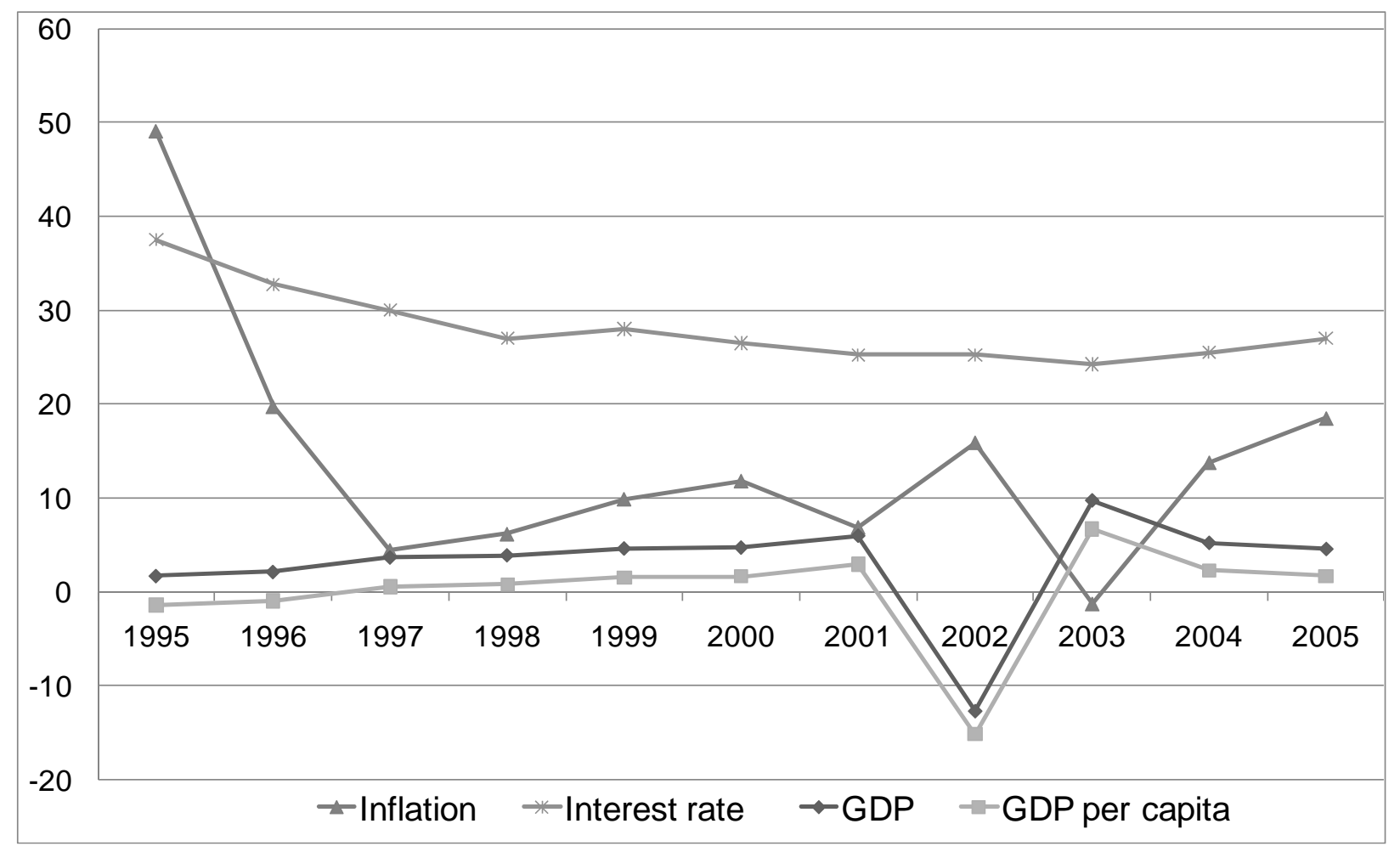

Figure 1: GDP growth, inflation and interest rate

(Source: World Development Indicators, The World Bank.

Note: The interest rate is the nominal lending rate to private customers.)

The growth process registered at the national level until 2001 is confirmed by the survey data that will be used in this paper (see Section 4). Urban households benefited most from the situation. In Antananarivo, the real average labor income increased by 53\% between 1995 and 2001, which corresponds to a huge $8 \%$ annual growth rate, an unprecedented pace in Madagascar's history (Razafindrakoto and Roubaud, 2002, 2010). Consequently, the poverty incidence decreased from 39\% to $19 \%$ while income inequality was also reduced. The 2002 crisis stopped this positive trend: the unemployment rate nearly doubled along with a massive increase in time-related underemployment ${ }^{3}$ and child labor. Real incomes dropped by 5\%. Thereafter, despite the quick macroeconomic recovery, household living conditions stagnated: in 2004, earnings were as low as in 2002, and in 2006, they were only $2 \%$ higher than during the crisis.

\footnotetext{
${ }^{3}$ A person is in a situation of time-related underemployment if he works less than 35 hours a week and wishes to work more.
} 


\section{The dynamics of the informal sector: Theoretical aspects and empirical evidence}

Standard macro-economic labor market theories viewed the informal sector essentially as the residual of a segmented labor market, caused by rigidities in the formal sector. The informal sector was therefore considered to be disguised unemployment in the absence of unemployment benefits. In contrast, others have argued that informal and formal labor markets are in fact competitive, and workers are, at the margin, indifferent between the two (Maloney, 2004). The sector in which they choose to work is optimal given their preferences and the constraints they face. They may switch from one to the other to take advantage of job opportunities. However empirical observation suggests that this is only likely to be true for a subset of workers (Fields, 2004). In fact empirical evidence shows that the informal sector is in many dimensions very heterogeneous, in terms of the motivation to be in this sector or of the employed capital and labor. It includes both involuntary salaried labor, queuing for formal jobs, and voluntary self-employment, the latter being similar in many respects to the entrepreneurial, small firm sector in developed countries. According to these theories, the informal sector thus comprises an upper tier, with modes of production and jobs similar to formal firms, and a lower tier, corresponding to the residual or subsistence sector in the dualistic view (Fields, 2004; Bosch and Maloney, 2010). However, Cunningham and Maloney (2001) show for Mexico that only a small fraction of firms actually corresponds to the dualistic view in which self-employment is the disadvantaged sector of a segmented market. Instead, their findings argue in favor of strong heterogeneity among small firms, of the same nature as in developed countries, where small firms that have reached their optimal long-run size co-exist with profitable starting firms and start-up firms that will not survive.

Non-convex production technologies combined with imperfect credit markets have been put forward by microeconomic theory to explain why many firms are stuck with low levels of capital and earnings, so called 'poverty traps' (Banerjee and Newman, 1993; Galor and Zeira, 1993). Indivisibilities in the production technology would create entry barriers to high return activities. Below a certain threshold of capital stock, entrepreneurs are trapped in activities yielding very low or zero returns. If in addition capital markets do not function for them, they are unable to invest enough to reach the necessary capital threshold and to converge to the optimal level of capital.

However, quite in line with Cunningham and Maloney (2001), a number of recent studies from diverse settings including Sri Lanka, Ghana, Kenya, West-Africa and Mexico have found very high returns to capital at low levels of capital in small-scale activities, thus contradicting the assumption of low subsistence returns at low levels of capital (McKenzie and Woodruff, 2006; Udry and Anagol, 2006; De Mel, et al., 2008; Kremer, et al., 2008; Fafchamps, et al., 2011; Grimm, et al., 2011). In addition, there is mixed evidence on the existence of high entry barriers (McKenzie and Woodruff, 2006; Udry and Anagol, 2006; Grimm, et al., 2011). ${ }^{4}$ These empirical findings are at odds with the idea of poverty traps and more generally with the idea that the informal sector relates to a large extent to subsistence activities. High returns at low levels of capital rather suggest that these firms have the potential to accumulate capital and possibly create jobs. To the best of our knowledge, capital accumulation in informal firms has been almost completely ignored in the empirical literature. This may be due to the possibly wrong - assumption that these firms do not accumulate. Another important reason is certainly the limited availability of data to assess this question.

\footnotetext{
${ }^{4}$ Though in some cases returns were rather small for female entrepreneurs. For a detailed review of the literature, see Grimm et al. (2011).
} 
Yet there are a number of studies, mostly rather recent, that look at the determinants of firm growth more broadly. Based on a number of country case studies, primarily from Sub-Saharan Africa, Mead and Liedholm (1998), for instance, find that at start-up, firms that are smaller grow more rapidly than those that are larger. They also find that younger informal firms grow faster than older firms. Based on their analysis the authors derive the following hypotheses regarding the relationship between economic expansion and firm growth. In times of macroeconomic growth, according to the authors, informal sector job creation is likely to be channeled mainly through firm expansion, while jobs would be destroyed as workers move to better economic opportunities, such as formal jobs. On the other hand, stagnation would lead to downsizing and more new firm creation. ${ }^{5}$

The results by Mead and Liedholm (1998) are largely in line with those obtained by Faijnzilber et al. (2006) for Mexican microenterprises. Faijnzilber et al. (2006) find an insignificant relationship between time in business and firm size growth, and a significant, negative effect of firm size on growth. This indicates that larger firms are more likely to have reached their optimal size. They conclude that microenterprises in Mexico show a dynamic pattern consistent with a number of standard results from the theoretical literature on firm dynamics. ${ }^{6}$ They further substantiate their findings by comparing Mexican and US microenterprises. This comparison shows remarkable similarities with respect to the dynamics of self-employment in both countries.

Firm performance and dynamics have also recently been studied by Byiers \& Iacovone (2011), using cross-country data and firm-level data collected in 2004 and 2007 in Madagascar. They first run a cross-country regression to investigate firm growth determinants using a pooled firm level dataset from 11 developing countries including India, Vietnam, Mauritius and several sub-Saharan African countries. They find a positive relationship between firm size growth and firm size. When using a panel of 135 Malagasy formal firms, they find a negative effect of firm age on growth. In the same study they also compare labor productivity in small informal firms with labor productivity in small formal firms. They systematically find lower labor productivity in formal firms which might be due, according to the authors, to the high costs of formalization. In line with what we will show below, they find considerable heterogeneity in performance indicators of informal MSE across sectors.

Apart from these studies, the literature on informal sector dynamics has rather focused on the reaction of the labor market to business cycles. The simple dualistic view implies that the informal sector follows counter-cyclical dynamics as positive shocks to the economy should raise formal employment and shrink the size of the informal sector. In contrast, taking the position that informal sector employment is voluntary as workers are indifferent between sectors at the margin, wages and employment in both sectors should move together, in a pro-cyclical way. With an upper and a lower tier of the informal sector, we can expect pro-cyclical movements in the upper tier and countercyclical in the lower tier (Bosch and Maloney, 2010). Maloney (2004) shows that the respective sizes (in terms of employment) and wages of the formal and informal sectors can in the short run move in opposite directions, as in Colombia after the 1995 recession or together as in Mexico during the recovery period of 1987-1992.

The above contributions on returns and MSE dynamics have considerably improved our understanding of informal activities. Yet, informal firms have seldom been studied in the context of longer cycles and sustained economic growth, especially in the African context. In particular, our analysis will be concerned with the dynamics of capital in the informal sector. If the informal sector primarily hosts individuals queuing for formal jobs in subsistence activities, economic growth will be accompanied by

\footnotetext{
${ }^{5}$ See also Nichter \& Goldmark (2009) for similar statements.

${ }^{6}$ See, for example, the model developed by Jovanovic (1982).
} 
decumulation of informal capital, as informal activities are globally abandoned for formal jobs. This may be particularly the case if workers with both relatively high human capital and high wealth are at the top of the "waiting list" for formal jobs. However, indifference at the margin between informality and formality makes such a scenario less plausible: potentially successful entrepreneurs may have little incentive to change sectors. Rather, they may capture the business opportunities offered by economic growth and possibly accumulate capital.

These considerations illustrate that capital accumulation patterns in the informal sector, or more generally, firm behavior during growth (as well as crisis) eventually depends on the nature and characteristics of informal activities. Reactions may differ across sectors, firm size and age. This is why the empirical analysis below will first provide a detailed picture of the characteristics of informal firms, including profits and capital stocks between 1995 and 2004. Then we will look at labor market dynamics and cyclicality before turning to an analysis of structural changes, growth patterns and returns to capital in the informal sector.

\section{Data presentation}

\subsection{1-2-3 Surveys}

We use data from the 1-2-3 Surveys, collected in Antananarivo between 1995 and 2004 (Rakotomanana, et al., 2003; Razafindrakoto, et al., 2009). These surveys were specifically designed to collect information among representative samples of informal firms. Phase 1 is a labor force survey, conducted every year since 1995, among 3,000 households. Principal and secondary activities of every member aged 10 years and over are recorded, including the type and status of the firm (formal/informal). This allows establishing a list of all informal firms headed by any member of a household (whether it is the main or the secondary activity). This serves as the sampling frame for phase 2, in which around 1,000 firms are surveyed. These have been randomly selected from the phase 1 listing. The stratification scheme - by industries (nine) and type of firms (with or without wage workers) - as well as an oversampling of the most atypical kind of firms (e.g. big manufacturing enterprises) make sure that the full heterogeneity of the informal sector is captured. In this paper we mainly use data from phase 2, i.e. the part that collects information on the characteristics of firms, such as the number and characteristics of hired paid and unpaid workers, investment, expenditures for intermediate inputs, fees and taxes, sales and profits. Finally, phase 3 is a household expenditure survey which interviews another representative sub-sample of households drawn from phase 1 . Hence, for a sub-sample of informal firms, information from all three phases is available. Phase 2 has been conducted every three years since the start of the 1-2-3 survey. Hence, we can use data on a representative sample of approximately 4,000 informal firms surveyed in 1995, 1998, 2001 or 2004.

Four key advantages of the 1-2-3 survey over other alternative datasets need to be stressed here. First, the mixed household-enterprise survey frame is the only one to ensure the full representativeness of the informal sector. Previous studies, especially in Africa, are typically based on enterprise surveys (like 'Regional Program on Enterprise Development' surveys) which cover only a part of all informal firms; in general the upper tier of the informal sector in some specific industries, mainly manufacturing. Second, our four rounds of surveys are fully comparable, as sampling methodology and questionnaire have been maintained constant over time. To our knowledge, this is the first time ever such a series of repeated cross sections on informal firms on a representative basis is available in Sub-Saharan Africa. Third, as informal firms do not usually keep books (and in many cases do not even have any written records), the survey questionnaire has been designed in order to assist the owners of the firms in establishing, product by product, all its sales and expenses, on a flexible period 
of time, adapted to each individual case. This detailed and comprehensive procedure to collect information is the only way to get reliable data, and to avoid the usual underestimation biases caused by more aggregate questions. The same extensive process is used to reconstitute the capital stock evaluated at replacement costs to take into account depreciation. Given that for each capital item, the date of purchase is collected, the full sequence of capital accumulation can be obtained, year by year. The only drawback is that we do not have information on capital goods that were fully depreciated or were sold in one of the previous periods. Fourth, the survey comprises a special module designed to capture monthly seasonality. Given the usually high intra-year fluctuations in the informal sector, this is again a significant advantage. In sum, our dataset offers a unique opportunity to get insights on the evolution and dynamics of the informal sector over a decade.

\subsection{Main characteristics of the informal sector}

Table 1 provides a summary of key characteristics of informal firms and their owners, both overall and disaggregating the sample by quartiles of capital stock. While the average age of the firms is around 8.7 years, the median age is 3.7 years lower, indicating that there are a lot of very young firms in the sample, and a few (much) older ones. Half of the informal firms are owned by women. Two thirds of informal firms are operated by the owner only.

Table 1: Basic characteristics of informal firms

\begin{tabular}{lcccccc}
\hline & \multicolumn{2}{c}{ Overall } & \multicolumn{3}{c}{ By quartile of capital stock } \\
\hline & Mean & Median & $1^{\text {st }}$ & $2^{\text {nd }}$ & $3^{\text {rd }}$ & 4th \\
\hline Age of the enterprise & 8.7 & 5.0 & 8.8 & 9.0 & 8.3 & 8.7 \\
Age of owner & 38.4 & 38.0 & 37.3 & 38.9 & 38.1 & 39.9 \\
Owner's education (in years) & 7.0 & 6.0 & 5.6 & 6.4 & 7.8 & 8.9 \\
Experience of owner (in years) & 8.2 & 5.0 & 8.5 & 8.4 & 7.8 & 7.9 \\
Female owner (=1) & 0.5 & 1.0 & 0.5 & 0.5 & 0.5 & 0.4 \\
Size of firm (total staff) & 1.5 & 1.0 & 1.2 & 1.5 & 1.6 & 1.8 \\
Pure self-employment (=1) & 0.7 & 1.0 & 0.9 & 0.7 & 0.6 & 0.5 \\
Monthly value added(1000 FMg) & 491.1 & 201.0 & 287.3 & 369.7 & 565.7 & 884.6 \\
Capital (1000 FMg) & $2,681.6$ & 341.0 & 21.5 & 254.7 & $1,347.1$ & $11,627.3$ \\
Zero capital stock (=1) & 0.1 & 0.0 & 0.3 & 0.0 & 0.0 & 0.0 \\
\hline \# Observations & 3,995 & 3,995 & 1,025 & 990 & 1,006 & 974 \\
\hline Souce: 1-2-3 Surveys, Phas
\end{tabular}

Source: 1-2-3 Surveys, Phase 2, 1995-2004, INSTAT/DIAL/MADIO; authors' calculations.

Notes: Quartiles are calculated separately for each year. Means are weighted using sampling weights. Monthly value added and capital stock are real values, deflated using the Consumer Price Index (source: INSTAT).

Table 1 also shows the mean and median of performance indicators such as value added, capital stock and capital stock at start-up. Value added is calculated as the difference between sales and intermediary consumption. Intermediary consumption includes raw material and inventory purchases, rent and utilities, and other expenses. Value added thus includes capital income, all labor income and entrepreneurial profits. Capital is the total stock of capital, again measured at the actual replacement value. To obtain real values, the Consumer Price Index (CPI) is used as a deflator. This is of course, at least from a conceptual point of view, not very satisfactory. Capital goods should be deflated over time using a specific price index, since the price of equipment, real estate or vehicles is likely to evolve differently from consumer prices, in particular from prices for basic food- and non-foodstuffs. Unfortunately, specific price indices for physical capital goods are not available in Madagascar (as in most others developing countries), which only provides a CPI and its components by large categories. To test the sensitivity of our results with respect to the deflator used, we alternatively deflated capital by the equipment, furniture and housing component of the CPI. This led to a very similar result in 
terms of the development of the capital stocks over time. Hence, in what follows we always apply the CPI.

Mean monthly value added is 491,000 Fmg (US\$49) while median value added is only 193,000 Fmg (US\$20), indicating substantial heterogeneity across firms. ${ }^{7}$ This is even more visible in the value of the capital stock, whose distribution is strongly skewed to the right. The mean is over 2,600,000 Fmg (US\$260) but the median is only $341,000 \mathrm{Fmg}$ (US\$34). There are a few firms operating with a very high capital stock, while the large majority owns very little or no capital at all. In fact, $10 \%$ of the firms operate with no physical capital whatsoever.

The most striking result is that apart from education and direct performance or size indicators such as employment and value added, there is not much variation in firm characteristics across quartiles. The age of the owner is slightly increasing, but the difference is relatively small with 2.7 years separating the average firm in the first quartile from the average firm in the fourth quartile. Even the gender of the owner does not vary much, only the top quartile has significantly more male owners than the other three quartiles. Average experience is slightly decreasing with capital, maybe surprisingly. However, education of the owner increases strongly with capital.

High capital firms are larger in terms of staff. In fact the large majority of firms operating with very little or no capital just employ the owner. While value added increases in a broadly linear manner across capital quartiles, the value of the capital stock increases ten-fold between the first and the second, and between the third and the fourth quartiles respectively. This suggests, at this stage, decreasing returns to capital.

Disaggregating the sample by sector of activity can provide additional insights on the different types of firms that operate in the informal sector. Eight sectors are defined: food processing, clothing and textile manufacturing, other industries, construction, trade, services to households and enterprises, catering and transport (Table 2). We also included in our table a variable measuring investment at start-up in order to assess the existence and extent of entry barriers in the informal sector. It is defined as the amount of physical capital purchased during the first year of activity, and is shown for the subsample of firms that are four years old or younger; the latter to minimize the recall bias with respect to the investments undertaken when the business started. This is of course only an imperfect approach to the problem of entry barriers, but we think that this can at least give a rough idea with respect to the minimum of capital needed to start in a specific sector.

There are some striking differences across sectors. Firstly, some activities are clearly gender-specific: textile and catering are feminine activities while construction and transport are almost entirely run by men. Older firms are concentrated in textile and other industries, construction and service activities. These sectors exhibit an average time in business of over nine years. On the other hand, catering, food processing and trade firms have been running for less than seven years on average. Interestingly, the size of the firm in terms of employment is not associated with its performance in terms of profit. Construction and transport have both high rates of pure self-employment and the highest mean value added of the sample. These two sectors stand out as extremes in terms of their capital stock. Capital profitability is very high in construction firms as the mean capital stock is the lowest of all sectors. At the other end of the distribution, $80 \%$ of transport firms are situated in the highest quartile of capital stock. This is due to the fact that vehicles represent the main type of investment in that sector. The two other sectors, in which firms are largely owner-operated, are services and textile manufacturing and

\footnotetext{
${ }^{7}$ The amounts in US Dollars are calculated using the current US\$-Malagasy Franc exchange rate.
} 
they have the lowest average value added. Half of all service firms have a capital stock below the $25^{\text {th }}$ percentile of the distribution. The catering sector appears rather well-performing from these descriptive statistics, with a larger size, high value added and capital stock.

Table 2: Basic characteristics of informal firms by sector

\begin{tabular}{lcccccccc}
\hline & Food & Textile & $\begin{array}{c}\text { Other } \\
\text { ind. }\end{array}$ & Construction & Trade & Services & Catering & Transport \\
\hline Age of the enterprise & 5.0 & 11.1 & 11.1 & 11.5 & 6.9 & 9.4 & 5.6 & 7.9 \\
Age of owner & 36.6 & 40.1 & 39.5 & 39.5 & 37.7 & 37.4 & 38.1 & 40.4 \\
Owner's education (years) & 7.2 & 8.1 & 6.3 & 6.2 & 6.6 & 6.8 & 7.3 & 8.2 \\
Experience of owner (years) & 4.5 & 10.6 & 10.0 & 11.1 & 6.2 & 9.1 & 5.6 & 7.8 \\
Female owner (=1) & 0.5 & 0.8 & 0.2 & 0.0 & 0.6 & 0.5 & 0.7 & 0.1 \\
Size of firm (staff) & 2.0 & 1.3 & 1.8 & 1.8 & 1.5 & 1.3 & 2.1 & 1.4 \\
Pure self-employment (=1) & 0.4 & 0.8 & 0.6 & 0.7 & 0.6 & 0.9 & 0.4 & 0.8 \\
Value added & 465 & 390 & 545 & 800 & 471 & 362 & 690 & 853 \\
Capital & 2,556 & 2,140 & 3,138 & 702 & 1,614 & 2,252 & 2,897 & 14,948 \\
\% in lowest capital quartile & 5.6 & 16.9 & 19.2 & 44.2 & 35.8 & 50.9 & 4.1 & 5.4 \\
\% in highest capital quartile & 20.2 & 23.8 & 25.8 & 3.9 & 13.1 & 15.5 & 24.2 & 79.7 \\
Initial investment & 2,814 & 2,814 & 2,662 & 594 & 1,242 & 2,189 & 2,449 & 13,039 \\
Months to recover initial & 4.4 & 8.1 & 3.0 & 0.2 & 0.6 & 1.3 & 2.5 & 16.0 \\
investment & & & & & & & & \\
\hline Source: & & & & & & & & \\
\hline
\end{tabular}

Source: 1-2-3 Surveys, Phase 2, 1995-2004, INSTAT/DIAL/MADIO; authors' calculations.

Notes: Means are calculated using sampling weights. Value added, capital stock and initial investment are expressed in 1,000 Fmg. Value added is monthly. The number of months necessary to recover initial investment is calculated at the median monthly profit of the sector.

\section{Results}

\subsection{Informal and formal labor market dynamics}

As mentioned in Section 3, the dynamics of the informal sector have mainly been studied from a labor market perspective. We first adopt this perspective too and then move on to issues of structural changes, growth patterns and returns to capital of firms.

As in other cities in SSA, the informal sector represents the largest share of employment in Antananarivo. Even if its share is 10 to 15 percentage points lower than in other West African urban centers, it remains the first job provider, totalizing more than one out of two jobs (Table 3). Taken as a whole and as can be seen in Table 3, the informal sector in Antananarivo seems to follow anti-cyclical dynamics. Between 1997 and 2001, its share steadily decreased, from $60 \%$ to $53 \%$ of total employment, reversing the previous process of informalization of the economy. This drop occurred in a context of public administration and state enterprise downsizing, as part of the structural adjustment program. In terms of employment, this process mainly benefited the private formal sector. This structural change was mainly due to the rapid development of EPZ and at least to some extent to the expansion of formal domestic enterprises. The average annual growth rate of employment over the period was $27 \%$ in EPZ but only 3\% in the informal sector. As shown by Table 3, in Antananarivo this led to a tripling of the share of EPZs in total employment between 1995 and 2001, from 3\% to more than $10 \%$, while the share of private formal sector jobs remained stagnant at $25 \%$ (Cling, et al., 2005).

The 2002 crisis totally reversed this trend. In less than one year, the informal sector 're-colonized' the labor market, absorbing the laid-off workers from closing formal enterprises and the new entrants, deprived from any alternative source of jobs. All the progress made during the five previous years was erased, and the informal sector grew up to its highest level since 1995 (59.5\% of total employment). While both dependent and independent informal employment increased, the growth in the number of informal entrepreneurs was much faster than the overall increase in the number of workers. This is a 
sign that informal sector employment growth is extensive rather than intensive, as it happens mainly through the creation of new firms rather than the expansion of employment in existing firms. Interestingly, in the period of growth (1998-2001), although dependent informal labor was absorbed in formal enterprises, the absolute number of firms continued to increase, even faster than the overall growth of the employed labor force. This suggests that the informal sector consists of both workers queuing for a formal job and voluntary entrepreneurs. Conversely, in the period of crisis and the following recovery, the decrease in formal employment seems to have been mainly compensated by an increase in informal independent labor (the share in total employment increases from 35 percent to $38.6 \%$ ), rather than informal hired or family labor, suggesting that existing firms were not able to absorb the surplus labor released by the formal sector, and most of these workers started an informal activity. Additionally, an important fraction of the fast growth in the number of informal firms is explained by new entries on the labor market.

Table 3: Share of employment by institutional sector 1995-2010 (\%)

\begin{tabular}{|c|c|c|c|c|c|c|c|c|c|c|c|}
\hline & 1995 & 1996 & 1997 & 1998 & 1999 & 2000 & 2001 & 2002 & 2004 & 2006 & 2010 \\
\hline Public sector & 14.2 & 14.3 & 13.0 & 13.2 & 13.1 & 10.6 & 10.7 & 11.2 & 10.4 & 8.8 & 7.8 \\
\hline Private formal sector & 25.1 & 22.6 & 22.9 & 24.6 & 24.2 & 25.3 & 25.9 & 24.9 & 22.2 & 25.2 & 22.4 \\
\hline EPZs & 3.1 & 4.4 & 4.6 & 5.5 & 6.7 & 8.9 & 10.2 & 4.1 & 8.9 & 8.0 & 4.8 \\
\hline Informal sector & 57.6 & 58.8 & 59.6 & 56.7 & 56 & 55.3 & 53.1 & 59.9 & 58.4 & 58 & 65.1 \\
\hline dependent & 27.6 & 22.6 & 25.2 & 22.8 & 21.5 & 20.3 & 18.9 & 21.3 & 19.9 & 21.7 & 30.6 \\
\hline independent & 30.0 & 36.2 & 34.4 & 33.9 & 34.5 & 35.0 & 34.2 & 38.6 & 38.5 & 36.3 & 34.5 \\
\hline Total & 100 & 100 & 100 & 100 & 100 & 100 & 100 & 100 & 100 & 100 & 100 \\
\hline Total (1,000 jobs) & 415 & 435 & 455 & 476 & 500 & 530 & 540 & 538 & 604 & 636 & 746 \\
\hline
\end{tabular}

Source: 1-2-3 Surveys, Phase 1, 1995-2010, INSTAT/DIAL/MADIO; authors' calculations.

Note: Private formal sector figures do not include EPZs.

The EPZ paid the highest tribute to the crisis, employment being divided by nearly three. From 2002 onwards, the EPZ recovers its pre-crisis number of jobs. Yet, recovery of domestic formal enterprises seemed to be limited (Cling, et al., 2009). Finally, as a second political turmoil occurred in 2009 combined with the international financial crisis, which resulted in a new drastic shock, the informal sector employment absorbed nearly two thirds of the labor force in 2010 (Rakotomanana, et al., 2010).

In terms of labor income, the informal sector is, as expected, the lowest paying segment of the urban labor market, with jobs in the public sector at the top of the earnings ladder (first row of Table 4). Interestingly, although it is significant, the earning gap with EPZs jobs is quite low, stressing the potential trade-offs in choosing one sector or the other for low skill workers, especially women (Glick and Roubaud, 2006). The decline in informal sector employment in the second half of the nineties was accompanied by large income gains from informal activities. Between 1995 and 2001, real average informal earnings increased by $66 \%$, this is more than the $53 \%$ registered over all sectors together. Given that the informal sector is less exposed to international competition than the formal tradable sector, informal firms have been able to benefit from the increase in domestic demand. In spite of the lower income elasticity of their products and of a decreasing market share for consumption goods (-6 percentage points), informal goods still satisfied nearly three quarters of household consumption in 2001. If only food is considered the share catered by the informal sector was even $95 \%$ (Razafindrakoto and Roubaud, 2010).

Conversely, in 2002, the average income in the informal sector was reduced by $11 \%$, while the decline for the whole labor market was 'only' 5\%. Shrinking aggregate demand combined with the absorption of labor quitting the formal sector are likely to be the main drivers of this sharp contraction. The shift from formal to informal consumption goods following the impoverishment of the population was not sufficient to counterbalance the two former effects (Razafindrakoto and Roubaud, 2010). On the 
contrary, the formal sector was able to maintain real wages, but at the expense of a massive reduction in jobs. These figures are consistent with the common belief that the formal sector would adjust during downturns through quantity, while price adjustment would be the main mechanism at work in the informal sector. Subsequently, informal sector incomes progressively recover part of their purchasing power, at least up to 2009 , before a new drastic drop occurred.

Table 4: Level and growth rates of earnings by institutional sector 1995-2010

\begin{tabular}{|c|c|c|c|c|c|c|c|c|c|c|c|}
\hline & \multicolumn{4}{|c|}{ Level } & \multicolumn{7}{|c|}{ Real growth rate $(1995=100)$} \\
\hline & 1995 & 1996 & 1997 & 1998 & 1999 & 2000 & 2001 & 2002 & 2004 & 2006 & 2010 \\
\hline $\mathrm{Pub}$ & 185 & 95.8 & 111.2 & 129.8 & 144.1 & 157.9 & 164.7 & 157.6 & 158.0 & 166.5 & 155.4 \\
\hline $\begin{array}{l}\text { Private formal } \\
\text { sector (excl. EPZs) }\end{array}$ & 136 & 91.7 & 123.3 & 137.8 & 133.5 & 143.2 & 143.8 & 148.3 & 149.8 & 151.7 & 126.0 \\
\hline EPZs & 79 & 31.4 & 37.8 & 15 & 155.4 & 167.7 & 168.5 & 169.9 & 171.8 & 176.2 & 176.8 \\
\hline Inforn & 69 & 112.1 & 125.6 & 43.8 & 161.9 & 165.3 & 166.2 & 147.8 & 153.6 & 158.0 & 138.5 \\
\hline Total & 103 & 100.1 & 117.8 & 136.3 & 145.4 & 150.1 & 153.1 & 144.9 & 145.4 & 148.6 & 128.6 \\
\hline
\end{tabular}

Source: 1-2-3 Surveys, Phase 1, 1995-2010, INSTAT/DIAL/MADIO; authors' calculations.

Notes: The first column corresponds to monthly earnings in 1,000 Fmg; the other columns to the earnings dynamics compared to 1995 .

Up to now, we analyzed informal sector dynamics through labor force survey data, which does not allow focusing on the productive aspects of employment. We also considered each sector as an aggregate without taking into account its intrinsic heterogeneity. Taking advantage of the survey data presented in Section 4 will now allow us to overcome these limitations.

\subsection{Main structural changes}

In this section, we hence describe the main changes in the structure and characteristics of informal firms over time, using the data from Phase 2 of the 1-2-3 survey collected in 1995, 1998, 2001 and 2004. The first remarkable result is, as can be seen in Table 5, that there is no substantial change in the distribution of the main socio-demographic characteristics of firm owners (e.g. in terms of gender or education) over time.

Value added of informal firms increased between 1995 and 2001, i.e. during the period of economic growth and fell afterwards as a result of the sharp economic contraction starting in 2001. This is in line with the observation of increasing informal incomes highlighted in the previous section. The average time in business of a firm increased steadily, starting with 8 years in 1995 and reaching an average of 9.5 years in the most recent survey. In fact, in 1995 over a fifth of all firms had started their activity a year before the survey. This proportion decreased to $16 \%$ in 2004 , while the share of older firms (4 years or more in business) increased by 10 percentage points. If we disaggregate this further by the size of the capital stock, we can see that this effect is particularly and surprisingly strong among low capital firms (below the median of the capital stock distribution). In the two lowest quartiles of capital stock the average age of firms has in fact increased by 2.5 years. ${ }^{8}$ This development is particularly pronounced between 2001 and 2004. Obviously it is impossible to explain these shifts in detail, given that we do not have information on exits and entries of firms, ${ }^{9}$ but, these findings suggest that new firms operating with very little capital did probably not survive the crisis. Put differently, a young age combined with low capital is likely to make firms very vulnerable.

\footnotetext{
${ }^{8}$ Results are not shown but available on request.

${ }^{9}$ More precisely, the mean firm size over time is driven by three forces: changes in size of surviving firms, exit of firms of a given size and entry of firms of a given size.
} 
Table 5 shows a notable change in the firm size distribution. It confirms that growth in the informal sector was mainly extensive. There is much more self-employment in 2004 than in 1995, and there are less firms in the range of two to four workers. Marginally, existing firms, successful enough to be relatively large, could have absorbed some of the excess labor laid off from formal firms. It is however mainly through the start-up of new activities that unemployed workers responded or had to respond to the crisis.

\section{Table 5: Basic characteristics and sectoral distribution of informal firms by year}

\begin{tabular}{lcccc}
\hline & 1995 & 1998 & 2001 & 2004 \\
\hline Characteristic of firm owner & & & & \\
Age of owner & 37.1 & 38.3 & 37.6 & 39.8 \\
Owner's education (in years) & 7.0 & 6.8 & 7.1 & 7.0 \\
Experience of owner (in years) & 7.4 & 8.0 & 7.7 & 9.1 \\
Female owner (=1) & 0.5 & 0.5 & 0.5 & 0.5
\end{tabular}

\section{Characteristics of firms}

Age of the enterprise

Time in business, 1 year or less

Time in business, 2 years

Time in business, 3 years

Time in business, 4 years or more

Size of firm (total staff)

Pure self-employment (\%)

Two workers $(\%)$

Three workers (\%)

Four workers (\%)

Five or more workers (\%)

Monthly value added (1000 FMg)

Capital (1000 FMg)

$\begin{array}{cccc}8.1 & 8.3 & 8.4 & 9.6 \\ 0.22 & 0.17 & 0.20 & 0.16 \\ 0.10 & 0.09 & 0.10 & 0.09 \\ 0.08 & 0.07 & 0.12 & 0.05 \\ 0.59 & 0.67 & 0.59 & 0.70\end{array}$

$\begin{array}{cccc}1.5 & 1.4 & 1.5 & 1.4 \\ 63.6 & 71.6 & 69.2 & 74.1 \\ 26.2 & 18.1 & 18.0 & 17.8 \\ 6.1 & 7.1 & 7.3 & 3.9 \\ 2.9 & 1.8 & 3.4 & 1.8 \\ 1.2 & 1.4 & 2.2 & 2.4\end{array}$

400.9

465.1

521.2

529.4

$2,554.9$

$3,149.2$

$2,824.3$

$2,306.3$

\section{Sectoral distribution of informal firms (\%)}

\section{Food processing}

Clothing and apparel

Other industry

Construction

Trade

Services

Catering

Transport
4.0

20.3

7.0

3.6

39.9

16.3

4.2

4.7
3.2

17.0

7.3

6.6

36.9

20.1

3.5

5.5
2.6

13.5

9.0

7.4

36.8

22.8

2.8

5.0
1.4

14.9

8.4

8.0

31.4

25.4

5.6

5.0

\footnotetext{
Total (absolute \#) 122,546 161,838 203,215 237,704

Source: 1-2-3 Surveys, Phase 2, 1995-2004, INSTAT/DIAL/MADIO; authors' calculations.

Notes: Means and percentages are calculated using frequency weights. The total is the absolute number of firms estimated using frequency weights. Monthly value added and capital stock are real values, deflated using the Consumer Price Index (source: INSTAT).
} 
Table 6: Sectoral distribution of employment and share of institutional sectors within each activity (\%)

\begin{tabular}{|c|c|c|c|c|}
\hline & 1995 & 1998 & 2001 & 2004 \\
\hline Food processing & 3.3 & 3.2 & 2.6 & 2.2 \\
\hline Formal sector & 33.8 & 38.1 & 43.6 & 54.7 \\
\hline Informal sector, dependent & 23.7 & 23.7 & 24.9 & 16.5 \\
\hline Informal sector, independent & 38.9 & 31.9 & 29.8 & 21.7 \\
\hline Clothing and apparel & 17.4 & 15.3 & 18.3 & 16.3 \\
\hline Formal sector & 24.3 & 17.2 & 9 & 3.7 \\
\hline$E P Z$ & 17.9 & 34 & 55.5 & 55.2 \\
\hline Informal sector, dependent & 24.4 & 15.2 & 8.5 & 8.3 \\
\hline Informal sector, independent & 33 & 33.3 & 26.8 & 32.7 \\
\hline Other industry & 7.4 & 7.9 & 8.7 & 8 \\
\hline Public sector & 11.3 & 14.2 & 8.3 & 8.6 \\
\hline Formal sector & 41.1 & 41.4 & 37.1 & 33.3 \\
\hline Informal sector, dependent & 24.8 & 12.5 & 17.5 & 22.5 \\
\hline Informal sector, independent & 21.8 & 28.3 & 33.1 & 33.2 \\
\hline Construction & 4.7 & 5.7 & 5.6 & 6.8 \\
\hline Formal sector & 42.5 & 34.2 & 32.4 & 21.2 \\
\hline Informal sector, dependent & 31 & 26.3 & 22.4 & 31.4 \\
\hline Informal sector, independent & 21.4 & 33.9 & 43.8 & 44.8 \\
\hline Trade & 22.6 & 22.7 & 22.4 & 21 \\
\hline Formal sector & 29.7 & 26.8 & 29.4 & 23.1 \\
\hline Informal sector, dependent & 19.2 & 16.2 & 16.6 & 15.2 \\
\hline Informal sector, independent & 50.2 & 56.4 & 53.4 & 61.6 \\
\hline Services to households and firms & 36.5 & 36.3 & 33.8 & 36.5 \\
\hline Public sector & 36.3 & 32.4 & 28.6 & 26.9 \\
\hline Formal sector & 17 & 19.8 & 25.6 & 25.2 \\
\hline Informal sector, dependent & 33.4 & 30.9 & 25.2 & 23.5 \\
\hline Informal sector, independent & 13.4 & 16.8 & 20.6 & 24.4 \\
\hline Catering & 4.1 & 3.5 & 2.8 & 4.3 \\
\hline Formal sector & 35.1 & 34.3 & 38.1 & 22.4 \\
\hline Informal sector, dependent & 28.8 & 28.2 & 18.7 & 28.5 \\
\hline Informal sector, independent & 35.5 & 33.6 & 38.9 & 48.4 \\
\hline Transport & 4 & 5.4 & 5.8 & 5 \\
\hline Public sector & 12.2 & 9.7 & 6.7 & 4.1 \\
\hline Formal sector & 44.1 & 44 & 53.2 & 48.7 \\
\hline Informal sector, dependent & 20.5 & 14.5 & 10.4 & 12.1 \\
\hline Informal sector, independent & 23.2 & 31.7 & 29.7 & 35 \\
\hline Total $(\%)$ & 100 & 100 & 100 & 100 \\
\hline Total $(1,000$ jobs $)$ & 383 & 447 & 512 & 570 \\
\hline
\end{tabular}

Source: 1-2-3 Surveys, Phase 1, 1995-2004, INSTAT/DIAL/MADIO; authors' calculations.

Notes: Figures in italics are the percentage of each institutional sector in the employment of a given sector. Total does not add up to a hundred because institutional sectors with a share inferior to $5 \%$ are not shown, to lighten the table. Percentages are calculated using frequency weights. The total is the absolute number of workers estimated using frequency weights, excluding the agricultural sector.

The increase in self-employment can also be related to changes in the sectoral distribution. As shown in Table 5, the biggest change occurred in fact at the sector level. First of all, while trade activities represented $40 \%$ of all informal firms in Antananarivo in 1995, this share was only $31 \%$ nine years later. Overall, the share of industrial activities, which comprise food, textile and other manufacturing, also decreased over time. While this can partly be explained by a reallocation of activities within the informal sector, formalization combined with the general decline in employment in industrial activities between 2001 and 2004 certainly also contributed to this reduction (see Table 6). For textile producing firms in particular, there was a clear shift of labor from informal to formal firms before 2001. This shift was partly reversed after 2001. This was due to competition in the labor market rather than the product market. Indeed, textile goods produced in EPZs are exported while those produced by 
informal firms are for the domestic market and workers seem to prefer employment in EPZs over informal employment. That trend had been interrupted between 2001 and 2004, as the crisis of 2002 resulted in the closing of many clothing factories in the EPZs. Surplus labor reallocated to the informal sector, in fact not only in textile activities. The share of transport and catering activities was stable. Services have gained the most over the decade, from $19.6 \%$ of all firms to $30 \%$. This trend does not seem to have been affected by the crisis, as it increased by 2.5 to 5 percentage points over each threeyear period. The increase in the share of the construction sector is also quite important, starting from less than $4 \%$ in 1995 and representing $8 \%$ of informal firms in 2004. During the growth episodes the demand for housing might have increased and triggered an increase of supply in response.

In order to better understand the underlying drivers of these sectoral shifts, we relate these changes to the amount of capital necessary to start an activity in these various sectors. We find that sectors which gained the most - services and construction - show rather low start-up investments, they usually operate on little physical capital and recover their initial investment very fast. This is documented in Table 2. This suggests that indeed low entry barriers encourage the start-up of less capital intensive activities such as petty reparations, car mechanics, laundering or hairdressing. In addition, industrial activities and transport exhibit high entry barriers and shrank or did at least not expand much over the observation period. Trade did also shrink despite low entry barriers, but this is probably due to entry costs in terms of required inventories not necessarily start-up investments. Surprisingly there also seems to be no straightforward link between the profitability of an activity (in terms of value added per capital stock) and its development over time, except for construction.

\subsection{Growth patterns}

In this section we examine the patterns of firm growth, in terms of both labor and capital. We start by looking at the development of the distribution of the average capital stock per firm by sector and year (Figure 2) and the total sectoral capital stock by year (Figure 3). Since we use sampling weights to compute the total capital stock, Figure 3 provides an estimation of the total capital stock of the informal sector by sector and year in Antananarivo. Overall, Figure 2 suggests a decumulation or stagnation of capital over time, except in the 1995 to 1998 period during which we observe an increase at least in the median capital stock. Overall, the total capital stock in the informal sector strongly increased over the first three years of the period considered, after which it seems to have rather stagnated. However, as mentioned above, the total number of informal firms increased over the entire decade. Again, extensive growth seems to be one driver of this development. Around $30 \%$ of all households own more than one informal firm. The survey includes a question on the projected use of a loan if the entrepreneur could obtain one for his or her activity. While a little less than half declared that they would invest it in the existing firm, about $40 \%$ declared that they would rather start another firm. Investing in a new firm rather than expanding an existing one is hence a common strategy. This is particularly true in the service sector where $50 \%$ of firm owners would opt for extensive rather than intensive growth.

Textile manufacturing firms show a significant decline in both the mean capital stock per firm and the total capital stock in that sector. As the share of this activity decreased, this indicates that, in addition to textile activities being less frequent, the remaining ones also have a lower capital stock on which they operate. Firms in the construction sector increased in number, but they operate on less and less capital as well. On the other hand, food processing businesses saw their median capital stock rise, while the total capital stock clearly decreased. As there are fewer firms in this sector in 2004, this suggests that only the food processing businesses that had a rather high capital stock are still active in 
2004, unlike the pattern observed for textile industries. Other sectors do not exhibit such clear patterns of capital accumulation or decumulation.
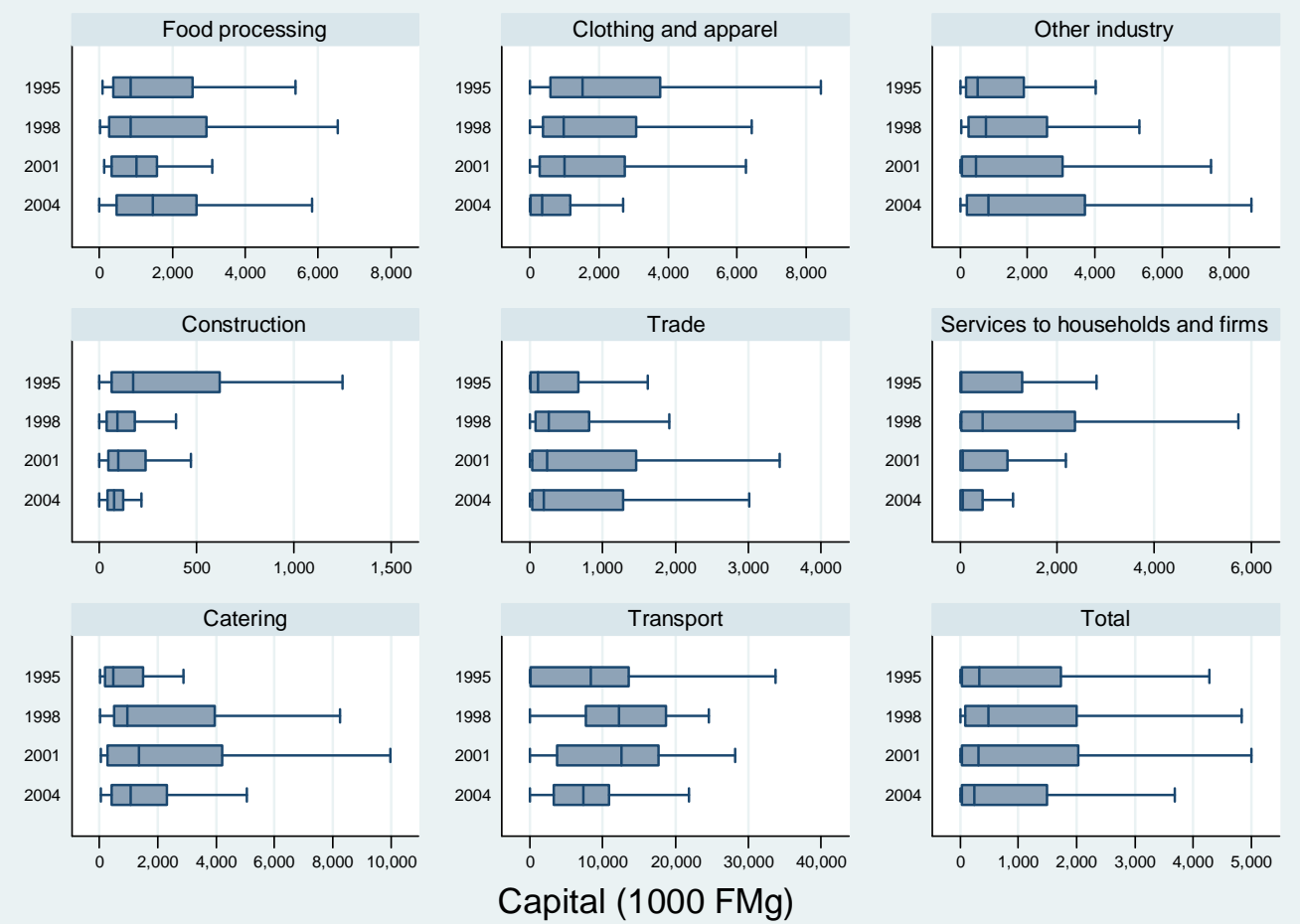

Figure 2: Capital stock box plot by sector

(Source: 1-2-3 Surveys, Phase 2, 1995-2004, INSTAT/DIAL/MADIO.)

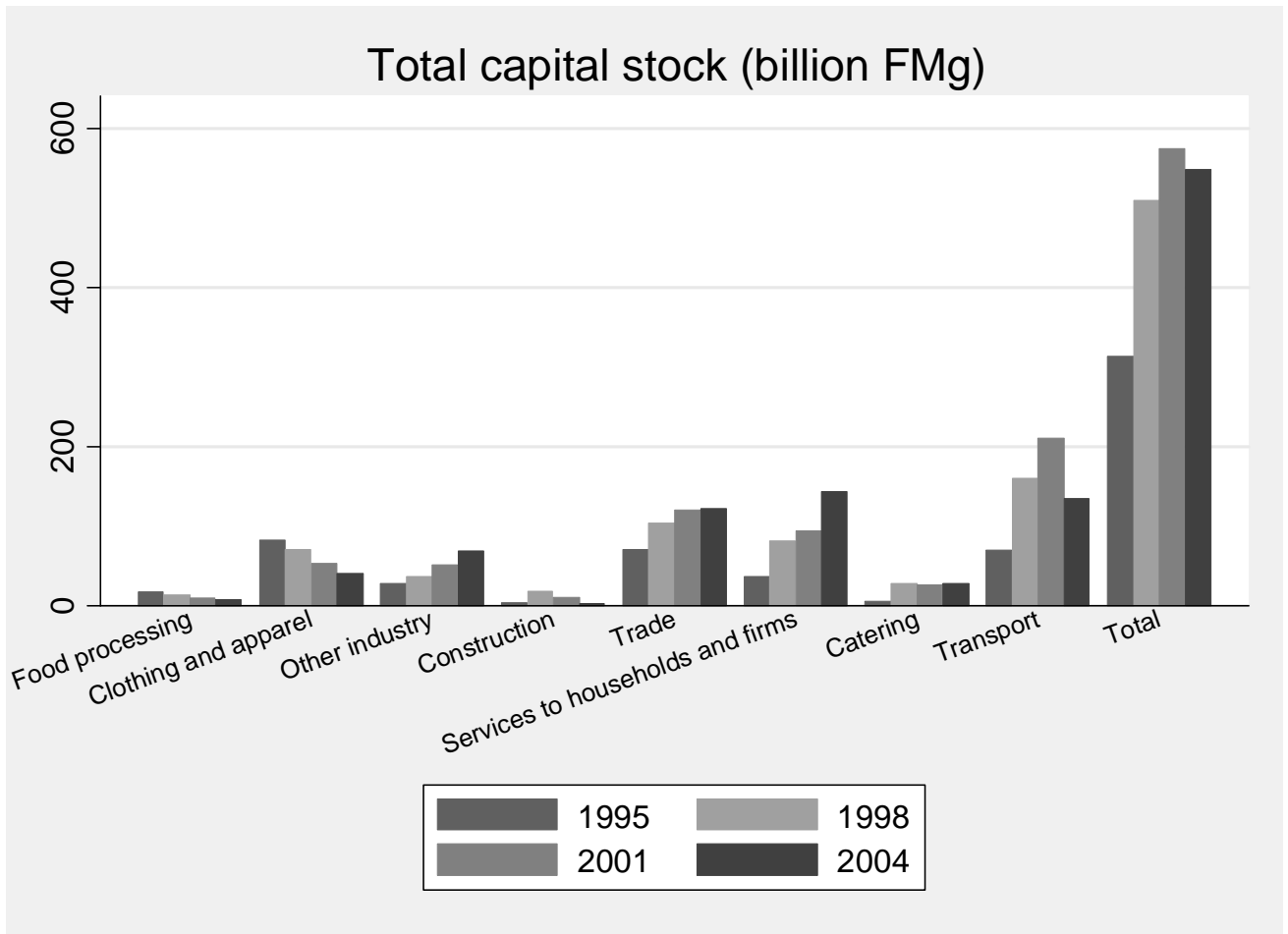

Figure 3: Total capital stock (billion Fmg)

(Source: 1-2-3 Surveys, Phase 2, 1995-2004, INSTAT/DIAL/MADIO.) 
We now turn to the development of firm size in terms of employed staff. Table 7 shows the proportion of firms which expanded, contracted or stagnated in terms of their staff. The survey asked respondents about the number of workers when the firm was set up ${ }^{10}$ and the number of workers at the time of the interview. This allows us to calculate employment growth rates at the firm level. However, to reduce recall bias problems we restrict our sample to firms that are ten years old or younger.

Table 7: Share of firms that contracted, stagnated or expanded since start-up

\begin{tabular}{lccc}
\hline & Contracted & Stagnated & Expanded \\
& $\%$ & $\%$ & $\%$ \\
\hline Overall & 4.6 & 83.2 & 12.3
\end{tabular}

\section{By start year}

1987-1989

1990-1992

$3.6 \quad 85.2$

$4.3 \quad 82.6$

11.2

1993-1995

6.5

78.7

13.1

1996-1998

4.0

81.8

14.8

1999-2001

4.2

84.9

14.2

2002-2004

3.9

91.4

11.0

\section{By sector}

Food processing

Clothing and apparel

Other industry

$5.5 \quad 72.1$

Construction

Trade

Services to households and firms

Catering

\section{By initial size}

Pure self-employment

$\begin{array}{ccc}0.0 & 88.0 & 12.0 \\ 17.5 & 71.2 & 11.3 \\ 24.8 & 60.0 & 15.1 \\ 29.1 & 51.2 & 19.6 \\ 26.5 & 36.8 & 36.7\end{array}$

Two workers

Three workers

Four workers

\section{By survey year}

$\begin{array}{lccc}1998 & 3.8 & 85 & 11.2 \\ 2001 & 5.3 & 80.3 & 14.4 \\ 2004 & 4.5 & 84.3 & 11.1\end{array}$

Source: 1-2-3 Surveys, Phase 2, 1998-2004, INSTAT/DIAL/MADIO; authors' calculations.

Notes: Percentages are calculated using frequency weights. Firms aged 10 years and less included in the table. The year 1995 is not included because the data on the number of workers at start-up is not available.

First we can note that the large majority, that is $83 \%$ of firms neither expanded nor contracted since their set-up. This is again consistent with our hypothesis on extensive firm growth. Second, firms surveyed in 2001 had expanded but also contracted more than firms surveyed before or after that date. This may be due to the overall dynamism of the economy, of which firms surveyed in 2001 benefited for the longest period of time. This would have generated both more employment growth in surviving

\footnotetext{
${ }^{10}$ Except in the 1995 survey in which this question was not asked.
} 
firms and more exits of very successful firms that have joined the formal sector. This is consistent with the stylized facts with respect to the relationship between firm growth and macroeconomic expansion which we discussed in Section 3.

Employment dynamics by sector yield further interesting insights. Textile manufacturing, transport and service firms in most cases stagnated, and show little expansion or contraction. On the other hand, some of the other sectors are very dynamic. For instance over $30 \%$ of the firms in the food processing and other industries, catering and construction businesses grew in size since their start-up. Food processing in particular exhibits close to no reduction in size at all. This is the only dynamic sector both in terms of employment growth and capital accumulation, while clothing and apparel businesses stagnated and decumulated capital. The food processing sector's decline in employment seems to be associated with a concentration process that resulted in fewer firms with a higher average size.

To further analyze the determinants of firm growth, we now run regressions of firm employment growth on a set of explanatory variables:

$$
\text { Growth }_{i}=\beta_{0}+X_{i}^{\prime} \beta_{1}+F_{i}^{\prime} \beta_{2}+S_{i}^{\prime} \beta_{3}+T^{\prime}{ }_{i} \beta_{4}+\varepsilon_{i} \text {. }
$$

The vector $X_{i}$ is a set of owner characteristics (age when started firm, female, marital status, education, number of firms owned by the household), $F_{i}$ is a vector of firm characteristics (initial size, time in business), $S_{i}$ is a vector of sector and $T_{i}$ is a vector of year dummies indicating the start-up year of the business. Firm employment growth is measured in three different ways. In the first model growth is the absolute difference between the actual and the initial labor force size, divided by the number of years in activity. In the second model, the dependent variable is the compound annual growth rate of employment. Finally an ordered probit is estimated, where the dependent variable takes three values, indicating contraction, stagnation and expansion. Results are shown in Table 8.

First we see that at least the models in columns (1) and (2) suggest that households owning a second firm have lower employment growth (per firm). This confirms again that many households engage in extensive growth rather than intensive growth. We do not find an equally negative effect for households with more than two firms, but this may have various reasons: there are only few households with three and more firms, which makes it difficult to get a reliable estimate. In addition, households with three and more firms may again have different motives and characteristics and thus engage in both expansion of existing firms and the set up of new firms.

Second, we note a convergence effect. Firms that started with two, three, four and more workers grow less than pure self-employment firms. This is in line with other findings on microenterprise growth in developing countries (Mead and Liedholm, 1998). However, in our case the same disclaimer as above applies. We lose of course firms that formalized. Hence, if these firms showed higher employment growth than firms that remained informal, our model would underestimate the extent of firm growth and the convergence effect would be biased.

Third, the regressions seem to suggest that the start year is rather irrelevant for firm growth. Fourth and finally, the sectoral dummies confirm what we saw already in our descriptive statistics. Catering and industrial activities experienced employment growth while service and transport activities contracted in terms of their staff. All these results are also confirmed by the ordered probit model. 
Table 8: Firm growth determinants, OLS and Ordered Probit regressions

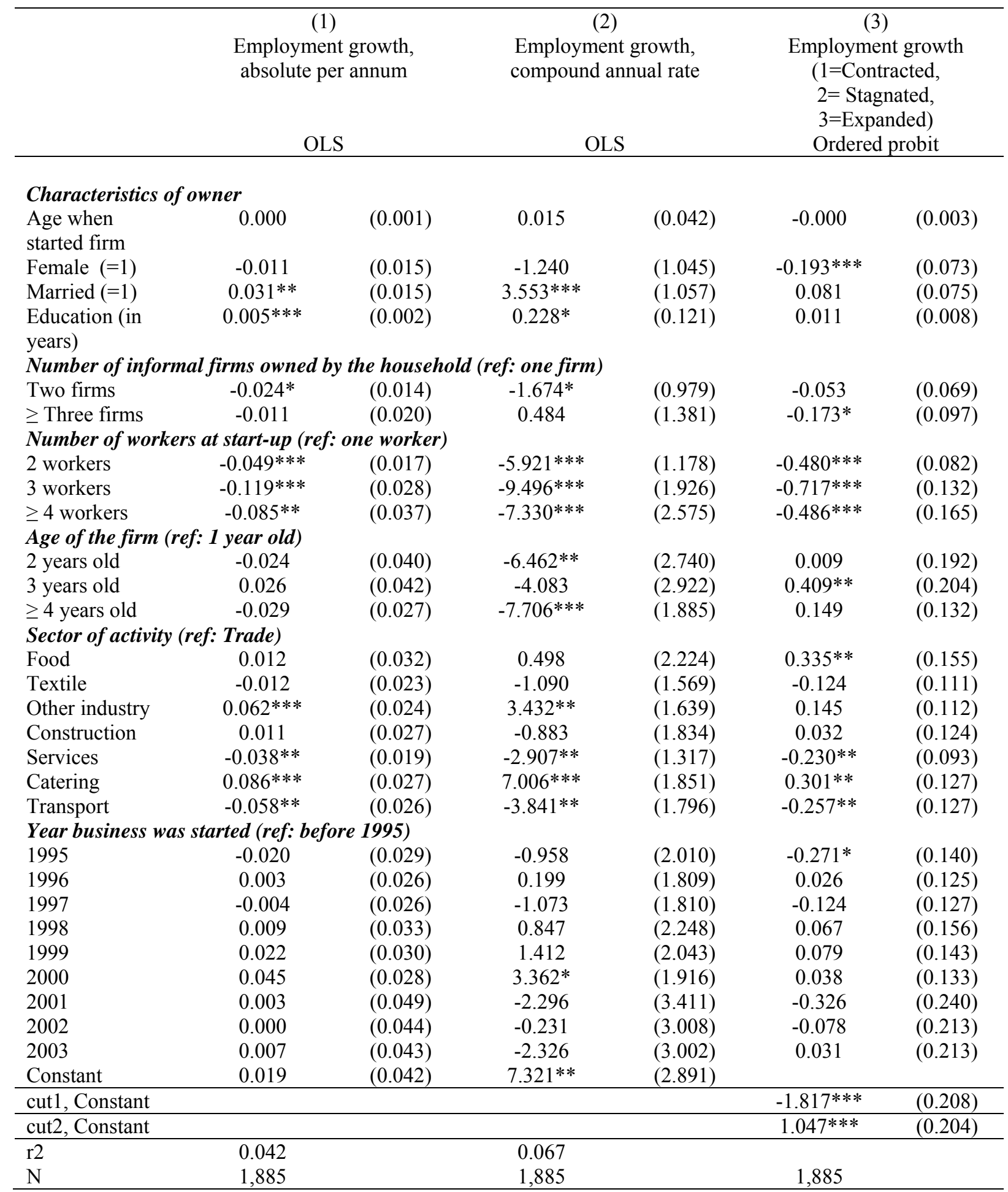

Source: 1-2-3 Surveys, Phase 2, 1998-2004, INSTAT/DIAL/MADIO; authors' calculations.

Notes: The year 1995 is not included because the data on the number of workers at start-up is not available. Regressions run on the sub-sample of firms aged 10 years and less. Standard errors in parentheses.

In sum, we must conclude from this exercise that the informal sector as a whole showed only little dynamics, both in terms of capital accumulation and employment growth. However, the heterogeneity across sectors is substantial. There are more small firms at the end of the period than in 1995. In addition, employment growth regressions show a convergence effect, which seems to indicate decreasing returns to factors, contrary to what is predicted by poverty trap models. Hence, after having analyzed the changes in the structure of the informal sector over time and the evolution of capital and 
labor, we now analyze how the returns to these factors, in particular capital, evolved over time. To this end, we estimate production functions by sector and different levels of capital stock.

\subsection{Returns to capital and labor}

We start by estimating marginal returns to capital on the pooled sample of firms. We estimate alternatively a logarithmic and a polynomial specification. The logarithmic specification reads

$$
\ln V A_{i}=\beta_{0}+\beta_{1} \ln K_{i}+\beta_{2} \ln L_{i}+X_{i}^{\prime} \beta_{3}+S_{i}^{\prime} \beta_{4}+T_{i}^{\prime} \beta_{5}+\varepsilon_{i},
$$

where $V A_{i}$ is the value added of firm $i, K_{i}$ is the stock of capital of the firm, $L_{i}$ the total number of hours worked in the firm both by paid and unpaid workers (such as family members). $X_{i}$ is a vector of owner characteristics such as gender, education and experience. The regression also includes year $T_{i}$ and sector $S_{i}$ indicators. The polynomial specification reads:

$$
V A_{i}=\beta_{0}+\beta_{1} K_{i}+\beta_{2} K_{i}^{2}+\beta_{3} L_{i}+\beta_{4} L_{i}^{2}+X_{i}^{\prime} \beta_{5}+S_{i}^{\prime} \beta_{6}+T^{\prime}{ }_{i} \beta_{7}+\varepsilon_{i} .
$$

The polynomial specification has the advantage of explicitly allowing for non-linearities in the marginal returns to capital and labor, while the logarithmic specification is less influenced by outliers. However, both specifications are of course potentially affected by an unobserved heterogeneity bias, which we can with the data at hand not appropriately tackle. For instance, in a context of imperfect capital markets, firms with a higher performance find it less difficult to invest and should end up with a higher capital stock. Another source of bias is of course measurement error.

We run these regressions on the entire sample as well as on three sub-samples defined by the level of capital of the firm. We define the median and the 80th percentile of the capital distribution as thresholds for low, medium and high levels of capital. ${ }^{11}$ These thresholds are calculated separately for each year. Firms operating with no capital are excluded from the regression as well as firms with zero profit. In addition, we drop influential outliers from the regression, identified by the DFITS-statistic (Belsley, et al., 2004). ${ }^{12}$

Results are shown in Table 9. We also report the implied marginal returns to capital (MRK) calculated at the mean levels of value added and capital. More precisely, to get the MRK based on the logarithmic specification, we calculate:

$M R K=\hat{\beta}_{1} * \overline{V A} / \bar{K}$,

where $\overline{V A}$ and $\bar{K}$ are the means of value added and capital respectively. The MRK based on the polynomial specification is simply given by:

$M R K=\hat{\beta}_{1}+2 \hat{\beta}_{2} \bar{K}$.

\footnotetext{
${ }^{11}$ These thresholds were chosen rather arbitrarily but results are robust to minor changes.

${ }^{12}$ Applying this procedure, we lose about $5 \%$ of the observations.
} 
Table 9: OLS estimates of returns to capital

\begin{tabular}{|c|c|c|c|c|c|c|c|c|}
\hline & \multicolumn{2}{|c|}{ all } & \multicolumn{2}{|c|}{ low levels of capital } & \multicolumn{2}{|c|}{ medium levels of capital } & \multicolumn{2}{|c|}{ high levels of capital } \\
\hline & $\log$ OLS & no-log OLS & $\log$ OLS & no-log OLS & $\log$ OLS & $\begin{array}{c}\text { no-log } \\
\text { OLS }\end{array}$ & $\log$ OLS & $\begin{array}{l}\text { no-log } \\
\text { OLS }\end{array}$ \\
\hline Log capital & $\begin{array}{c}0.14 * * * \\
(0.01)\end{array}$ & & $\begin{array}{c}0.10^{* * *} \\
(0.02)\end{array}$ & & $\begin{array}{l}0.12 * * \\
(0.05)\end{array}$ & & $\begin{array}{c}0.43 * * * \\
(0.06)\end{array}$ & \\
\hline Capital (1000 & & $0.02 * * *$ & & $0.22 *$ & & $0.15 * * *$ & & -0.00 \\
\hline & & $(0.00)$ & & $(0.12)$ & & $(0.06)$ & & $(0.01)$ \\
\hline Capital & & 0.00 & & -0.00 & & $-0.00 * *$ & & $0.00 * *$ \\
\hline & & $(0.00)$ & & $(0.00)$ & & $(0.00)$ & & $(0.00)$ \\
\hline Log labor & $\begin{array}{c}0.56^{* * *} \\
(0.02)\end{array}$ & & $\begin{array}{c}0.54 * * * \\
(0.03)\end{array}$ & & $\begin{array}{c}0.57 * * * \\
(0.04)\end{array}$ & & $\begin{array}{c}0.48 * * * \\
(0.08)\end{array}$ & \\
\hline Total labor & & $\begin{array}{c}0.81 * * * \\
(0.11)\end{array}$ & & $\begin{array}{c}0.32 * * \\
(0.15)\end{array}$ & & $\begin{array}{c}0.97 * * * \\
(0.16)\end{array}$ & & $\begin{array}{c}1.46^{* * * *} \\
(0.28)\end{array}$ \\
\hline Total labor & & $0.00^{* * *}$ & & $0.00^{* * *}$ & & 0.00 & & 0.00 \\
\hline & & $(0.00)$ & & $(0.00)$ & & $(0.00)$ & & $(0.00)$ \\
\hline Owner's & $0.06^{* * *}$ & $20.43 * * *$ & $0.06^{* * *}$ & $12.15 * * *$ & $0.05 * * *$ & $17.41 * * *$ & $0.05 * * *$ & $34.49 * * *$ \\
\hline & $(0.00)$ & $(2.37)$ & $(0.01)$ & $(2.44)$ & $(0.01)$ & $(4.52)$ & $(0.01)$ & (8.29) \\
\hline Experience of & $0.01 * * *$ & $1.98 * *$ & $0.01 * *$ & 1.19 & 0.00 & 0.57 & 0.01 & 5.16 \\
\hline & $(0.00)$ & $(0.84)$ & $(0.00)$ & $(0.78)$ & $(0.00)$ & $(1.83)$ & $(0.00)$ & $(3.42)$ \\
\hline Female owner & $-0.30 * * *$ & $-78.01 * * *$ & $-0.28 * * *$ & $-77.03 * * *$ & $-0.30 * * *$ & $-69.59 * *$ & $-0.29 * *$ & $-150.78 * *$ \\
\hline & $(0.04)$ & (19.52) & $(0.06)$ & (18.33) & $(0.07)$ & (34.43) & $(0.11)$ & $(75.64)$ \\
\hline Year 1998 & $\begin{array}{c}0.28 * * * \\
(0.05)\end{array}$ & $\begin{array}{c}79.59 * * * \\
(22.17)\end{array}$ & $\begin{array}{c}0.32 * * * \\
(0.07)\end{array}$ & $\begin{array}{c}53.79 * * \\
(22.31)\end{array}$ & $\begin{array}{l}0.21 * * \\
(0.09)\end{array}$ & $\begin{array}{c}52.94 \\
(42.05)\end{array}$ & $\begin{array}{c}0.41 * * * \\
(0.12)\end{array}$ & $\begin{array}{l}152.95^{*} \\
(88.83)\end{array}$ \\
\hline Year 2001 & $\begin{array}{c}0.48^{* * *} \\
(0.06)\end{array}$ & $\begin{array}{c}131.06^{* * *} \\
(26.38)\end{array}$ & $\begin{array}{c}0.60 * * * \\
(0.07)\end{array}$ & $\begin{array}{c}106.98^{* * *} \\
(25.24)\end{array}$ & $\begin{array}{c}0.34 * * * \\
(0.10)\end{array}$ & $\begin{array}{l}83.73^{*} \\
(43.08)\end{array}$ & $\begin{array}{c}0.48^{* * *} \\
(0.13)\end{array}$ & $\begin{array}{l}126.61 \\
(98.04)\end{array}$ \\
\hline Year 2004 & $\begin{array}{c}0.50 * * * \\
(0.06)\end{array}$ & $\begin{array}{c}155.16^{* * *} \\
(24.08)\end{array}$ & $\begin{array}{c}0.60 * * * \\
(0.07)\end{array}$ & $\begin{array}{c}128.03^{* * * *} \\
(23.17)\end{array}$ & $\begin{array}{c}0.41^{* * *} \\
(0.09)\end{array}$ & $\begin{array}{c}113.80 * * \\
(44.02)\end{array}$ & $\begin{array}{c}0.41 * * * \\
(0.13)\end{array}$ & $\begin{array}{l}150.07 \\
(95.13)\end{array}$ \\
\hline Food ind. & $\begin{array}{l}-0.13 \\
(0.08)\end{array}$ & $\begin{array}{l}-53.77 \\
(34.84)\end{array}$ & $\begin{array}{c}-0.23 * * \\
(0.10)\end{array}$ & $\begin{array}{c}-121.77 * * * \\
(28.82)\end{array}$ & $\begin{array}{c}0.15 \\
(0.16)\end{array}$ & $\begin{array}{l}-69.24 \\
(63.01)\end{array}$ & $\begin{array}{l}-0.09 \\
(0.19)\end{array}$ & $\begin{array}{c}36.65 \\
(159.86)\end{array}$ \\
\hline Textile & $\begin{array}{c}-0.42 * * * \\
(0.06)\end{array}$ & $\begin{array}{c}-50.52 * * \\
(24.72)\end{array}$ & $\begin{array}{c}-0.44 * * * \\
(0.08)\end{array}$ & $\begin{array}{c}-87.94 * * * \\
(22.97)\end{array}$ & $\begin{array}{c}-0.35^{* * *} * \\
(0.11)\end{array}$ & $\begin{array}{l}-63.49 \\
(47.07)\end{array}$ & $\begin{array}{l}-0.27 \\
(0.17)\end{array}$ & $\begin{array}{c}-8.81 \\
(117.26)\end{array}$ \\
\hline Other ind. & $\begin{array}{c}-0.17 * * * \\
(0.06)\end{array}$ & $\begin{array}{l}-12.20 \\
(31.90)\end{array}$ & $\begin{array}{c}-0.31 * * * \\
(0.08)\end{array}$ & $\begin{array}{c}-84.96^{* * *} \\
(28.10)\end{array}$ & $\begin{array}{l}-0.00 \\
(0.11)\end{array}$ & $\begin{array}{c}74.26 \\
(59.65)\end{array}$ & $\begin{array}{l}-0.00 \\
(0.17)\end{array}$ & $\begin{array}{c}72.06 \\
(127.96)\end{array}$ \\
\hline Construction & $\begin{array}{c}0.34 * * * \\
(0.07)\end{array}$ & $\begin{array}{c}68.37^{* *} \\
(34.06)\end{array}$ & $\begin{array}{c}0.33^{* * *} * \\
(0.08)\end{array}$ & $\begin{array}{c}80.92 * * \\
(31.93)\end{array}$ & $\begin{array}{c}0.47 * * * \\
(0.17)\end{array}$ & $\begin{array}{c}307.83 * * \\
(148.85)\end{array}$ & $\begin{array}{l}-0.04 \\
(0.20)\end{array}$ & $\begin{array}{c}-3.67 \\
(254.06)\end{array}$ \\
\hline Services & $\begin{array}{c}-0.16^{* * *} \\
(0.06)\end{array}$ & $\begin{array}{l}-42.44 * \\
(25.31)\end{array}$ & $\begin{array}{c}-0.22 * * * \\
(0.07)\end{array}$ & $\begin{array}{c}-83.43 * * * \\
(21.46)\end{array}$ & $\begin{array}{l}-0.17 \\
(0.11)\end{array}$ & $\begin{array}{l}-49.90 \\
(49.23)\end{array}$ & $\begin{array}{c}0.25 \\
(0.15)\end{array}$ & $\begin{array}{c}151.24 \\
(114.53)\end{array}$ \\
\hline Catering & $\begin{array}{c}0.03 \\
(0.07)\end{array}$ & $\begin{array}{l}-5.41 \\
(34.62)\end{array}$ & $\begin{array}{l}-0.10 \\
(0.09)\end{array}$ & $\begin{array}{l}-46.49 \\
(31.35)\end{array}$ & $\begin{array}{c}0.17 \\
(0.12)\end{array}$ & $\begin{array}{c}18.91 \\
(65.22)\end{array}$ & $\begin{array}{c}0.27 \\
(0.20)\end{array}$ & $\begin{array}{c}-81.08 \\
(166.62)\end{array}$ \\
\hline Transport & $\begin{array}{c}0.04 \\
(0.08)\end{array}$ & $\begin{array}{c}25.64 \\
(46.94)\end{array}$ & $\begin{array}{l}-0.10 \\
(0.14)\end{array}$ & $\begin{array}{c}-144.28^{* * *} \\
(39.51)\end{array}$ & $\begin{array}{c}-0.50 * * * \\
(0.15)\end{array}$ & $\begin{array}{c}-166.90^{* *} \\
(72.23)\end{array}$ & $\begin{array}{c}0.12 \\
(0.14)\end{array}$ & $\begin{array}{c}238.07 * * \\
(106.59)\end{array}$ \\
\hline Constant & $\begin{array}{c}1.11 * * * \\
(0.13)\end{array}$ & $\begin{array}{c}-81.89 * * \\
(37.96)\end{array}$ & $\begin{array}{c}1.35^{* * * *} \\
(0.19)\end{array}$ & $\begin{array}{c}44.20 \\
(37.91) \\
\end{array}$ & $\begin{array}{c}1.31 * * * \\
(0.46)\end{array}$ & $\begin{array}{l}-115.72 \\
(91.02)\end{array}$ & $\begin{array}{l}-1.07^{*} \\
(0.57)\end{array}$ & $\begin{array}{c}-219.74 \\
(153.20)\end{array}$ \\
\hline R-squared & 0.451 & 0.399 & 0.398 & 0.299 & 0.340 & 0.259 & 0.401 & 0.357 \\
\hline $\mathrm{N}$ & 3,456 & 3,446 & 1,731 & 1,761 & 1,026 & 1,036 & 680 & 676 \\
\hline $\begin{array}{l}\text { Mean value } \\
\text { added (VA) }\end{array}$ & 561 & 447 & 354 & 289 & 547 & 476 & 1141 & 909 \\
\hline $\begin{array}{l}\text { Mean capital } \\
(\mathrm{K})\end{array}$ & 3,611 & 2,880 & 194 & 192 & 1,931 & 1,928 & 15,083 & 14,424 \\
\hline $\begin{array}{l}\text { Implied MRK } \\
\text { (at mean VA } \\
\text { and K) }\end{array}$ & 0.022 & 0.022 & 0.180 & 0.159 & 0.034 & 0.042 & 0.032 & 0.005 \\
\hline
\end{tabular}

Source: 1-2-3 Surveys, Phase 2, 1995-2004, INSTAT/DIAL/MADIO; authors' calculations.

Note: Capital in thousand FMg. Robust standard errors corrected for clustering at the "segment" level in parentheses. MRK: marginal monthly return to capital. * $\mathrm{p}<0.1 * * \mathrm{p}<0.05 * * * \mathrm{p}<0.01$. 
Before we discuss the coefficients of main interest, we briefly discuss some of the effects associated with the control variables. We notice a strong negative gender effect. On average, value added is significantly lower for women, even after controlling for sector and the level of capital stock. The time dummies indicate that the increase in value added over the entire period is significant, however value added of high-capital firms is lower in 2004 than in 2001. This suggests that capital-rich firms benefit more in times of growth but also suffer more in times of crisis. Such a result is consistent with Gubert \& Roubaud (2011), who assessed the impact of microfinance loans on informal firms in Madagascar between 2001 and 2004, based on a quasi-experimental approach and panel data analysis. As suggested by the descriptive analysis the textile manufacturing sector appears to be the least profitable sector while transport and construction are the most profitable sectors.

As shown in the first two columns of Table 9, the implied marginal returns to capital are $2.2 \%$. However, at low levels of capital, returns are much higher. An entrepreneur operating at the average level of capital of 194,000 Fmg and realizing the average monthly value added of 354,000 Fmg would increase his or her monthly value added by $18 \%$ if the equivalent of $10,000 \mathrm{Fmg}$ (approximately \$1) is added to the capital stock. Although the estimated production elasticities are higher in the medium and high range of capital, implied marginal returns calculated at average value added and capital are with $0.5 \%$ to about $5 \%$ substantially lower than in the lower segment of the capital distribution. Decreasing returns to capital contradict the standard theory of poverty traps, but are in line with findings from other studies on Africa, Latin America and Asia (see Section 3). This finding may also explain why we observe such little growth in firm size and capital stock. Lower returns at high levels of capital suggest that firms reach their optimal size at a relatively low level of capital and labor. Yet, it is of course important to note that looking just at informal firms means that we ignore all those firms that graduated from the informal to the formal sector. It is of course possible that those enterprises that grow in terms of capital and staff and that manage to realize increasing returns become formal in large numbers. However, the employment distribution over time in Table 3 suggests that the number of formal firms did not evolve much and rather decreased than increased. Moreover, there is not much evidence that formalization would boost productivity of rather small firms. Byiers \& Iacovone (2011), for instance, find a lower productivity in formal micro firms compared to informal micro firms. They speculate that this may at least partly be linked to the relatively high costs of formalization and the rather low quality of public services that entrepreneurs get in return.

Next, we analyze the change in marginal returns over time by adding year interaction terms to the list of regressors. Results are shown in Table 10. We note that the MRKs are remarkably stable over time (around 2\%). However, looking again at the MRKs estimated for the different segments of the capital distribution we get a more contrasting story. At low levels of capital, the increase in the MRK is quite important, leaping from $8 \%$ to $25 \%$. The negative coefficients of the year indicators show that this segment did not globally benefit from economic growth during the studied decade. In contrast, at medium and high levels of capital, marginal returns to capital were globally stable or decreasing. 
Table 7: Test of parameter equality across years.

\begin{tabular}{|c|c|c|c|c|}
\hline & $\begin{array}{c}\text { All levels of } \\
\text { capital }\end{array}$ & $\begin{array}{c}\text { Low level of } \\
\text { capital }\end{array}$ & $\begin{array}{c}\text { Medium level } \\
\text { of capital }\end{array}$ & $\begin{array}{c}\text { High level of } \\
\text { capital }\end{array}$ \\
\hline Log capital & $\begin{array}{c}0.156^{* * *} \\
(0.019)\end{array}$ & $\begin{array}{l}0.060^{* *} \\
(0.028)\end{array}$ & $\begin{array}{c}0.059 \\
(0.155)\end{array}$ & $\begin{array}{c}0.307 * * * \\
(0.096)\end{array}$ \\
\hline Log capital*year 1998 & $\begin{array}{c}0.011 \\
(0.026)\end{array}$ & $\begin{array}{c}0.083 * * \\
(0.042)\end{array}$ & $\begin{array}{c}0.146 \\
(0.177)\end{array}$ & $\begin{array}{c}0.326^{* *} \\
(0.140)\end{array}$ \\
\hline Log capital*year 2001 & $\begin{array}{l}-0.015 \\
(0.025)\end{array}$ & $\begin{array}{c}0.028 \\
(0.038)\end{array}$ & $\begin{array}{c}0.086 \\
(0.193)\end{array}$ & $\begin{array}{l}-0.008 \\
(0.143)\end{array}$ \\
\hline Log capital*year 2004 & $\begin{array}{l}-0.032 \\
(0.025)\end{array}$ & $\begin{array}{c}0.027 \\
(0.040)\end{array}$ & $\begin{array}{l}-0.083 \\
(0.180)\end{array}$ & $\begin{array}{c}0.021 \\
(0.141)\end{array}$ \\
\hline Log labor & $\begin{array}{c}0.565 * * * \\
(0.045)\end{array}$ & $\begin{array}{c}0.439 * * * \\
(0.057)\end{array}$ & $\begin{array}{c}0.541 * * * \\
(0.094)\end{array}$ & $\begin{array}{c}0.899 * * * \\
(0.107)\end{array}$ \\
\hline Log labor*year 1998 & $\begin{array}{c}0.002 \\
(0.056)\end{array}$ & $\begin{array}{c}0.054 \\
(0.073)\end{array}$ & $\begin{array}{c}0.122 \\
(0.111)\end{array}$ & $\begin{array}{c}-0.527 * * * \\
(0.135)\end{array}$ \\
\hline Log labor*year 2001 & $\begin{array}{l}-0.015 \\
(0.057)\end{array}$ & $\begin{array}{c}0.236 * * * \\
(0.070)\end{array}$ & $\begin{array}{c}0.021 \\
(0.113)\end{array}$ & $\begin{array}{c}-0.349 * * \\
(0.136)\end{array}$ \\
\hline Log labor*year 2004 & $\begin{array}{l}-0.009 \\
(0.063)\end{array}$ & $\begin{array}{l}0.157^{* *} \\
(0.078)\end{array}$ & $\begin{array}{c}0.014 \\
(0.117)\end{array}$ & $\begin{array}{l}-0.268^{*} \\
(0.149)\end{array}$ \\
\hline Year 1998 & $\begin{array}{c}0.120 \\
(0.338)\end{array}$ & $\begin{array}{l}-0.525 \\
(0.407)\end{array}$ & $\begin{array}{l}-1.703 \\
(1.562)\end{array}$ & $\begin{array}{c}0.432 \\
(1.337)\end{array}$ \\
\hline Year 2001 & $\begin{array}{c}0.633^{* *} \\
(0.321)\end{array}$ & $\begin{array}{c}-1.013 * * \\
(0.392)\end{array}$ & $\begin{array}{l}-0.429 \\
(1.653)\end{array}$ & $\begin{array}{r}3.058^{* *} \\
(1.381)\end{array}$ \\
\hline Year 2004 & $\begin{array}{l}0.770 * * \\
(0.339)\end{array}$ & $\begin{array}{l}-0.622 \\
(0.393)\end{array}$ & $\begin{array}{c}1.043 \\
(1.524)\end{array}$ & $\begin{array}{c}2.063 \\
(1.332)\end{array}$ \\
\hline $\begin{array}{l}\text { R-squared } \\
\mathrm{N}\end{array}$ & $\begin{array}{l}0.444 \\
3,453\end{array}$ & $\begin{array}{l}0.394 \\
1,721\end{array}$ & $\begin{array}{l}0.342 \\
1,028\end{array}$ & $\begin{array}{c}0.447 \\
6,75\end{array}$ \\
\hline $\begin{array}{l}\text { F-Test: All log-capital } \\
\text { interactions }=0\end{array}$ & 0.275 & 0.264 & 0.274 & 0.064 \\
\hline $\begin{array}{l}\text { F-Test: All log-labor } \\
\text { interactions }=0\end{array}$ & 0.987 & 0.003 & 0.513 & 0.002 \\
\hline $\begin{array}{l}\text { F-Test: All owner's education } \\
\text { interactions }=0\end{array}$ & 0.607 & 0.111 & 0.452 & 0.038 \\
\hline Implied MRK 1995 & 0.02 & 0.08 & 0.02 & 0.02 \\
\hline Implied MRK 1998 & 0.02 & 0.18 & 0.06 & 0.04 \\
\hline Implied MRK 2001 & 0.02 & 0.18 & 0.03 & 0.02 \\
\hline Implied MRK 2004 & 0.02 & 0.25 & -0.01 & 0.03 \\
\hline
\end{tabular}

Source: 1-2-3 Surveys, Phase 2, 1995-2004, INSTAT/DIAL/MADIO; authors' calculations.

Notes: Controls not shown: owner's education interacted with year, experience, gender, sector dummies. Robust standard errors corrected for clustering at the "segment" level in parentheses. MRK: marginal monthly return to capital. * $\mathrm{p}<0.1 * * \mathrm{p}<0.05 * * * \mathrm{p}<0.01$.

Given the sectoral heterogeneity discussed earlier in this paper, we now run the same regressions on sub-samples by sector. Table 11 shows again the implied MRKs. ${ }^{13}$ Food processing and other industries are aggregated in a single sector to ensure that the sample size is large enough to get a reliable estimate. Yet, we refrain from estimating MRKs for the transport and construction sectors given the small sample sizes. We find for all sectors the same pattern: decreasing returns to capital. Catering exhibits the highest returns among the five sectors we consider overall and for low and medium levels of capital. Trade exhibits very rapidly decreasing returns. Returns are lowest in the textile sector and weakly decreasing but only at very low levels of capital. Marginal returns are in fact

\footnotetext{
${ }^{13}$ The full set of regressions is available on request.
} 
nil in capital-intensive trade firms. Hence, what we concluded above for the informal sector as a whole is also confirmed at the sectoral level: there are only very modest growth prospects, which again may explain extensive growth rather than intensive growth.

Table 8: Marginal returns to capital by sector

\begin{tabular}{lcccc}
\hline & $\begin{array}{c}\text { All levels of } \\
\text { capital }\end{array}$ & $\begin{array}{c}\text { Low level of } \\
\text { capital }\end{array}$ & $\begin{array}{c}\text { Medium level of } \\
\text { capital }\end{array}$ & $\begin{array}{c}\text { High level of } \\
\text { capital }\end{array}$ \\
\hline Food and other ind. & 0.024 & 0.061 & 0.024 & 0.009 \\
Textile & 0.017 & 0.048 & 0.026 & 0.026 \\
Trade & 0.030 & 0.168 & 0.031 & -0.002 \\
Services & 0.021 & 0.127 & 0.057 & 0.020 \\
Catering & 0.066 & 0.191 & 0.080 & 0.016 \\
\hline
\end{tabular}

Source: 1-2-3 Surveys, Phase 2, 1995-2004, INSTAT/DIAL/MADIO; authors' calculations.

Notes: Implied marginal returns to capital by sector calculated at the mean of capital and value added in each sector. The elasticities are estimated for each sector and level of capital separately. Full set of regressions available on request.

\subsection{Returns to capital and labor at the sector level}

In this final section, we again estimate returns to capital and labor. However, now we estimate these production functions at the sector level and not at the level of individual firms. This analysis should provide us with an estimate of the 'macroeconomic' or 'social' marginal returns to capital. More precisely, we construct a pseudo-panel of cohorts based on the age of the firm and the sector of activity. ${ }^{14}$ Pseudo-panels rely on the assumption that in each cross-section, the firms surveyed are a random, representative sample of the cohort to which they belong. This assumption is fulfilled in the case of the Malagasy 1-2-3 survey. So, we take the mean value added of each cohort in each period and regress it on the mean of the various covariates, in particular physical capital, and control for timeinvariant cohort fixed effects (Deaton, 1985). Cohorts are defined by the year of birth of the firm. To ensure that each cohort is large enough, we group firms in three-year periods (1987-1989; 1990-1992; 1993-1995; 1996-1998; 1999-2001; 2002-2004). Given the low number of very old firms, we aggregate all firms born before 1987 in a single cohort. We also have to aggregate again some of the sectors. Hence, we consider four aggregated sectors: food and other manufacturing industries, textile and clothing, trade of primary and transformed goods and services and catering. Again, the transport and construction sectors are dropped because the number of observations is too small and they do not fit very well in any of the other categories. The analysis is therefore carried out using a sample of 28 cohort-sector cells, each observed in the four rounds of the survey. ${ }^{15}$

We estimate two models, without and with cohort-sector fixed effects. The first model is:

$$
\ln Y_{i j t}=\alpha+\beta_{1} \ln K_{i j t}+\beta_{2} \ln L_{i j t}+\beta_{3} X_{i j t}+T_{t}^{\prime} \beta_{4}+S_{j}^{\prime} \beta_{5}+\left(T_{t} \times S_{j}\right)^{\prime} \beta_{6}+\varepsilon_{i j t},
$$

where subscript $i$ refers to the cohort, $j$ to the sector, and $t$ to the survey year. Capital $K_{i j t}$, labor $L_{i j t}$ and owner characteristics $X_{i j t}$ are cohort means in each year. $T_{t}$ are year indicators, and $S_{j}$ are sector dummies. Ignoring fixed effects may have an advantage in cases where there is only a very modest variation in capital within cohorts. The model with cohort-sector fixed effects reads:

\footnotetext{
${ }^{14}$ A difference with a standard cross-sector panel is that here we stick to cohorts and thus stick to firms that survive over time. Firms that drop out are likely to be different from the survivors; hence there are potential selection effects involved.

${ }^{15}$ Cohorts of firms born after 1995 obviously have fewer observations than those born before.
} 
$\ln Y_{i j t}=\lambda_{i j}+\beta_{1} \ln K_{i j t}+\beta_{2} \ln L_{i j t}+\beta_{3} X_{i j t}+T_{t}^{\prime} \beta_{4}+\left(T_{t} \times S_{j}\right)^{\prime} \beta_{5}+\varepsilon_{i j t}$,

where $\lambda_{i j}$ is a cohort-sector fixed effect. Results of the pseudo-panel estimation are shown in Table 12.

Table 9: Pseudo-panel estimation of returns to capital and labor

\begin{tabular}{|c|c|c|}
\hline & $\begin{array}{c}\text { Log monthly value added } \\
\text { OLS }\end{array}$ & $\begin{array}{l}\text { Log monthly value added } \\
\text { Cohort-sector Fixed Effects }\end{array}$ \\
\hline Log capital & $\begin{array}{l}0.195^{* *} \\
(0.078)\end{array}$ & $\begin{array}{c}0.089 \\
(0.095)\end{array}$ \\
\hline Log labor & $\begin{array}{c}0.468^{* * *} \\
(0.170)\end{array}$ & $\begin{array}{l}0.531^{* *} \\
(0.198)\end{array}$ \\
\hline Education of owner (years) & $\begin{array}{c}0.028 \\
(0.042)\end{array}$ & $\begin{array}{l}-0.022 \\
(0.049)\end{array}$ \\
\hline Experience of owner (years) & $\begin{array}{c}0.005 \\
(0.006)\end{array}$ & $\begin{array}{c}0.014 \\
(0.045)\end{array}$ \\
\hline Female owner $(=1)$ & $\begin{array}{c}-0.892 * * * \\
(0.310)\end{array}$ & $\begin{array}{c}-0.924 * * \\
(0.377)\end{array}$ \\
\hline Year 1998 & $\begin{array}{c}0.432 * * \\
(0.169)\end{array}$ & $\begin{array}{c}0.428 * * \\
(0.212)\end{array}$ \\
\hline Year 2001 & $\begin{array}{l}0.298^{*} \\
(0.166)\end{array}$ & $\begin{array}{c}0.304 \\
(0.284)\end{array}$ \\
\hline Year 2004 & $\begin{array}{c}0.546 * * * \\
(0.157)\end{array}$ & $\begin{array}{c}0.542 \\
(0.390)\end{array}$ \\
\hline Textile sector & $\begin{array}{l}-0.017 \\
(0.269)\end{array}$ & \\
\hline Trade sector & $\begin{array}{l}0.542 * * \\
(0.224)\end{array}$ & \\
\hline Services and catering sector & $\begin{array}{c}0.173 \\
(0.189)\end{array}$ & \\
\hline Constant & $\begin{array}{l}1.445 \\
(0.932)\end{array}$ & $\begin{array}{l}2.265^{* *} \\
(1.104)\end{array}$ \\
\hline $\begin{array}{l}\mathrm{N} \\
\text { Implied marginal returns to capital }\end{array}$ & $\begin{array}{c}88 \\
0.04\end{array}$ & $\begin{array}{c}88 \\
0.02\end{array}$ \\
\hline
\end{tabular}

Source: 1-2-3 Surveys, Phase 2, 1995-2004, INSTAT/DIAL/MADIO; authors' calculations.

Notes: ${ }^{*} \mathrm{p}<0.1 * * \mathrm{p}<0.05 * * * \mathrm{p}<0.01$. Both regressions include sector*time interaction variables, not shown in the table.

The model without cohort fixed effects uses the variation between and within sector cohorts while controlling for time-varying sector effects. The results of this estimate are surprisingly similar to the above estimates that use the disaggregated information at the firm level. Both the capital and labor coefficients are significant and with about 0.2 for capital and 0.5 for labor of a very similar magnitude to the previous estimates. The estimated production elasticity of capital is also very much in line with macro-level estimates in low-income countries. ${ }^{16}$ At first sight, the estimated production elasticity of capital suggests that the sector aggregates of informal firms behave according to standard economic theory, i.e. according to standard neo-classical production technologies. With its low levels of capital stock - compared to larger firms - we should see capital accumulation in the informal sector. Why this does not happen in the aggregate becomes apparent when we consider capital productivity and the implied MRK reported in Table 12. Average capital productivity is so low that monthly marginal returns are only about $3 \%$, which explains why so little capital flows into these activities - in

\footnotetext{
${ }^{16}$ See e.g. Caselli (2005).
} 
particular if investors are not able to distinguish high and low return firms in the informal sector. This result is of course due to the heterogeneity of returns in informal firms that we have shown just above and driven by the low capital productivity in relatively large informal firms in terms of capital stock. The heterogeneity demonstrated by the disaggregated return estimates in the previous sub-section in conjunction with the finding of low aggregate capital returns can be taken as a sign that the informal sector is extremely inefficient in allocating capital across firms.

The second set of results using a cohort fixed effect does not lead to a significant coefficient for capital, but the labor-output elasticity is again in the same range as the micro-level estimates. The insignificant production elasticity of capital indicates that there is only a very limited variation in capital within single cohorts and that the between-cohort within-sector variation is likely to be the main driver of the first set of results - yet taking into account that we control for sector, year, and sector-year effects. The finding that the cohort fixed-effect estimate provides a labor output elasticity of very similar magnitude suggests that informal firms - as expected - adjust to changing macroeconomic conditions mainly by adjusting labor inputs.

\section{Conclusions}

This paper is a first attempt to analyze in detail structural change in the informal sector in a poor subSaharan African country over a long period. The context we have chosen is particularly interesting because it refers to a period of fragile growth, characterizing many African countries today. We started by relating overall dynamics of this sector to the macroeconomic changes that have occurred during the observation period. We then compared the informal sector in terms of aggregated employment dynamics over time to those in other sectors. We then looked at sectoral changes within the informal sector over time and analyzed the dynamics of the two most important production factors: capital and labor. We completed this analysis by estimating the returns to these factors and their changes over time. Overall, the observed behavior of informal firms in terms of earnings, employment and capital accumulation supports a theoretical framework that goes beyond the simple dualistic model and even beyond a more refined version of it that would distinguish between an upper entrepreneurial and a lower subsistence tier.

However, as usually assumed by these simple dualistic models, the informal sector indeed fulfills a labor absorbing function in times of crisis. In the Malagasy case, this seems to happen through creating new informal firms rather than absorbing labor into existing ones. The fact that labor formerly employed in informal firms is being absorbed by formal activities in the Export Processing Zones is also in line with the dualistic view. Employment in informal clothing and apparel firms decreases considerably in the period under consideration. This is due to competition on the labor rather than the product market, as workers choose to work in EPZs rather than in informal firms. In contrast, a number of other findings point to parts of the informal sector and its firms as a very dynamic segment of the Malagasy economy. During the growth period we see capital accumulation in most of the sectors and lots of evidence that households expand their activities. However, in contrast to labor absorption into informal firms, this happens mainly in the form of extensive informal sector growth, i.e. through the creation of new firms instead of the expansion of existing ones. This behavior is consistent with much higher returns at very low levels of capital, as accumulation at the extensive margin may then imply that the household is able to reap those marginal returns. In addition, risk diversification strategies may at least partly explain this observation. More rapid expansion can be observed in sectors that operate with lower capital intensity, which is also consistent with risk or credit constraints as major deterrents to expansion. 
While there is some indication that total factor productivity increased over time, returns to capital and labor where not higher at the end of the observation period than at the beginning. Returns are also rather low at high levels of capital. These findings point to a limited growth potential of the informal sector as a whole. Yet, there seems to be a sub-segment of informal firms that is able to earn high marginal returns albeit at very low levels of capital. The heterogeneity in capital returns hints at large inefficiencies in allocating capital across informal firms. Although this paper does not explicitly address the causes of the observed pattern, we hypothesize that these inefficiencies could be linked to the macroeconomic and political context which seems to be not very conducive for entrepreneurial activities. Furthermore, constraints that arise directly at the level of the firm, such as capital market imperfections and high risks in conjunction with risk aversion are likely to be important causes of this inefficient capital allocation. Finally, an important drawback of our study is that we cannot trace successful informal enterprises that eventually become formal. Although we do not expect this to happen for a large number of firms, including them would probably allow drawing a slightly more optimistic picture. 


\section{References}

Banerjee, A, and A Newman. (1993). Occupational choice and the process of development. Journal of Political Economy, 101(2), 274-298.

Belsley, D.A., E. Kuh, and R.E. Welsch. (2004). Regression diagnostics: Identifying influential data and sources of collinearity (Vol. 546): Wiley-Interscience.

Bosch, M., and W.F. Maloney. (2010). Comparative analysis of labor market dynamics using markov processes: An application to informality. Labour Economics, 17(4), 621-631.

Byiers, B, and L Iacovone. (2011). An Analysis of Pre-Crisis Madagascar Firm Performance: Firm Growth and Productivity. Paper presented at the CSAE Annual Conference 2011, Oxford, United Kingdom.

Caselli, F. (2005). Accounting for cross-country income differences. In Aghion \& Durlauf (Eds.), Handbook of economic growth (Vol. 1, pp. 679-741): Elsevier.

Cling, J.P., M. Razafindrakoto, and F. Roubaud. (2005). Export Processing Zones in Madagascar: a Success Story under Threat? World Development, 33(5), 785-803.

Cling, J.P., M. Razafindrakoto, and F. Roubaud. (2009). Export Processing Zones in Madagascar: The Impact of the Dismantling of Clothing Quotas on Employment and Labor Standards. In Robertson, Brown, Pierre \& Sanchez-Puerta (Eds.), Globalization, Wages, and the Quality of Jobs (pp. 237-264). Washington D.C.: The World Bank.

Cunningham, W.V., and W.F. Maloney. (2001). Heterogeneity among Mexico's microenterprises: an application of factor and cluster analysis. Economic Development and Cultural Change, 50(1), 131-156.

De Mel, S, D McKenzie, and C Woodruff. (2008). Returns to Capital in Microenterprises: Evidence from a Field Experiment. Quarterly Journal of Economics, 123(4), 1329-1372.

Deaton, A. (1985). Panel data from time series of cross-sections. Journal of Econometrics, 30(1-2), 109-126.

Fafchamps, M, D McKenzie, S Quinn, and C Woodruff. (2011). When is capital enough to get female microenterprises growing? Evidence from a randomized experiment in Ghana.Unpublished manuscript.

Fajnzylber, P., W. Maloney, and G.M. Rojas. (2006). Microenterprise dynamics in developing countries: How similar are they to those in the industrialized world? Evidence from Mexico. The World Bank Economic Review, 20(3), 389.

Fields, G.S. (2004). A Guide to Multisector Labor Market Models. Paper prepared for the World Bank Labor Market Conference, 2005.

Galor, O, and J Zeira. (1993). Income distribution and macroeconomics. The Review of Economic Studies, 60(1), 35-52.

Glick, P., and F. Roubaud. (2006). Export Processing Zone Expansion in Madagascar: What are the Labour Market and Gender Impacts? Journal of African Economies, 15(4), 722.

Grimm, M, J Lay, and Jens Krüger. (2011). Barriers of entry and capital returns in informal activities: Evidence from Sub-Saharan Africa.Unpublished manuscript.

Gubert, F., and Anne-Sophie Robilliard. (2010). Croissance et pauvreté à Madagascar: un aperçu de la dernière décennie (1997-2007). In Gastineau, Gubert, Robilliard \& Roubaud (Eds.), Madagascar face au défi des Objectifs du millénaire pour le développement (pp. 25-52). Marseille: IRD.

Gubert, F., and F. Roubaud. (2011). The Impact of Microfinance Loans on Small Informal Enterprises in Madagascar. A Panel Data Analysis.Unpublished manuscript.

Jovanovic, B. (1982). Selection and the Evolution of Industry. Econometrica, 50(3), 649-670.

Kremer, M, JN Lee, and JM Robinson. (2008). The Return to Capital for Small Retailers in Kenya: Evidence from Inventories. Manuscript, Harvard University.

Maloney, WF. (2004). Informality revisited. World Development, 32(7), 1159-1178.

McKenzie, D., and C. Woodruff. (2006). Do Entry Costs Provide an Empirical Basis for Poverty Traps? Evidence from Mexican Microenterprises. Economic Development and Cultural Change, 55(1), 3-42.

Mead, D.C., and C. Liedholm. (1998). The dynamics of micro and small enterprises in developing countries. World Development, 26(1), 61-74. 
Rakotomanana, F., E. Ramilison, and F. Roubaud. (2003). The creation of an annual labour force survey in Madagascar. An example for sub-saharan Africa. InterStat(27), 35-58.

Rakotomanana, F., M. Razafindrakoto, F. Roubaud, and J.-M. Wachsberger. (2010). The economic impact of the political crisis on urban households in Madagascar. The labour market in Antananarivo in 2010:looking back over ten years. Paris: DIAL.

Razafindrakoto, M., and F. Roubaud. (2002). Madagascar à la croisée des chemins: la croissance durable est-elle possible? Afrique contemporaine, 75-92.

Razafindrakoto, M., and F. Roubaud. (2010). La pauvreté urbaine à Madagascar: dynamique, déterminants et politiques. In Gastineau, Gubert, Robilliard \& Roubaud (Eds.), Madagascar face au défi des Objectifs du millénaire pour le développement (pp. 87-118). Marseille: IRD.

Razafindrakoto, M., F. Roubaud, and C. Torelli. (2009). Measuring the informal sector and informal employment: the experience drawn from 1-2-3 surveys in African countries. . African Statistical Journal, 9(Special Issue), 88-147.

Udry, C, and S Anagol. (2006). The return to capital in Ghana. The American Economic Review, 96(2), 388-393. 